\title{
Seismic-stratigraphic architecture of the Oligocene-Pliocene Camaná Formation, southern Peruvian forearc (Province of Arequipa)
}

\author{
Aldo Alván ${ }^{1,2,5}$, Astrid Criales ${ }^{3}$, Hilmar von Eynatten ${ }^{2}$, Istvan Dunkl ${ }^{2}$, Axel Gerdes ${ }^{4}$, Javier Jacay $^{5}$ \\ ${ }^{1}$ Laboratorio BIZALAB, Calle Aldabas No 626, Santiago de Surco, Lima, Perú. \\ aalvan@bizalab.com \\ ${ }^{2}$ University of Göttingen, Geoscience Center, Department of Sedimentology and Environmental Geology, Goldschmidtstrasse 3, \\ D-37077, Germany. \\ hilmar.von.eynatten@geo.uni-goettingen.de; istvan.dunkl@geo.uni-goettingen.de \\ ${ }^{3}$ Universidad de San Martín de Porres, Laboratorio de Investigación Aplicada, Facultad de Ingeniería y Arquitectura. Avda. La \\ Fontana 1250, La Molina, Lima, Perú. \\ acriales@usmp.pe \\ ${ }^{4}$ University of Frankfurt, Institute of Geosciences, Altenhofer Allee 1, D-60431, Germany. \\ gerdes@em.uni-frankfurt.de \\ ${ }^{5}$ Universidad Nacional Mayor de San Marcos, Facultad de Ingeniería Geológica. Avda. Venezuela Cuadra 34, Lima, Perú. \\ j_jacay@yahoo.com
}

\begin{abstract}
The Camaná-Mollendo Basin is an active-margin depression NW-SE elongated, which is located in the forearc of southern Perú and extends from the Coastal Cordillera to the Perú-Chile Trench. This basin consists of a grabens and half-graben complex, filled with deltaic and fluvial sedimentary rocks of the Oligocene-Pliocene Camaná Formation ( $\sim 500 \mathrm{~m}$ thick). An integration of compiled onshore stratigraphic logs, reinterpreted $2 \mathrm{D}$ seismic offshore information, sediment provenance data, and previous zircon $\mathrm{U}-\mathrm{Pb}$ geochronology on volcanic reworked ash supports a refined tectono-chronostratigraphic framework for the whole Camaná-Mollendo Basin fill. To complete this integration we needed firstly to elaborate a geological reinterpretation of seismic offshore data and highlight their most prominent features (i.e., erosive surfaces). This step allowed establishing a first correlation between onshore and offshore deposits of Camaná Formation by means of their sequence boundaries, giving as result a consistent division for Camaná Formation: (i) "CamA Unit" (coarse-grained deltas) and (ii) "CamB Unit" (fluvial deposits). CamA Unit is further subdivided into three subunits based on minor erosive surfaces (i.e., A1: Oligocene, A2: Early Miocene, and A3: Middle Miocene). CamA reflects prograding geometry (subunits A1 and A2) as well as onlapping geometry (subunit A3). CamB Unit (Late Miocene to Pliocene) consists of high-energy hyperpycnal flows composed of fluvial conglomerates in onshore, which very possibly changes to progradational deltaic in offshore. Each one of these units and subunits extends offshore and preserves similarities in depositional geometry and sequence boundaries with Camaná Formation onshore. Subunits A1 and A2 observed in offshore are grouped in this paper as "A1+A2" (Oligocene to Middle Miocene) because they show similar progradational geometry and it is difficult to differentiate them from each other. A regressive systems tract (RST) represents these subunits. These deposits reach up to $\sim 2.5 \mathrm{~km}$ thick, and they are intensely affected by normal faulting associated to pinch-out depositional geometry. Strata of subunit A3 (Middle Miocene) reflect a transgressive systems tract (TST), and blanket the entire basin with fine-grained sediments. These deposits are up to $\sim 1 \mathrm{~km}$ thick, being less affected by synsedimentary tectonic and show minor effects of synsedimentary tectonics. Finally, deposition of CamB Unit (Late Miocene to Pliocene) occurred during a new regressive systems tract (TST), which turned to progradational geometry similar to deltaic deposits in offshore, and according to seismic lines they are much less affected by synsedimentary faulting. Stratigraphic boundaries between "A1+A2" and A3, and between A3 and CamB observed in onshore outcrops are used here as tools to differentiate, correlate and predict the main depositional geometries in offshore. High-frequency seismic reflectors represent such boundaries and support divisions and subdivisions within Camaná Formation. These boundaries are also used to define depocentres of Camaná Formation along the entire CamanáMollendo Basin, where the thickests are located in the proximity of the large river mouths (e.g., Planchada, Camaná, and Punta de Bombón). Strata of subunits "A1+A2" are considered as potential reservoir for hydrocarbon due to their
\end{abstract}


high rate of sediment accumulation. Deposits of A3 are transgressive and they are considered as potential potential seal rock. Structurally, Camaná-Mollendo Basin is composed of graben and half-graben components $\sim$ NW-SE-oriented, typical of a trantensional tectonic regime.

Keywords: Camaná-Mollendo Basin, Cenozoic, Sequence stratigraphy, Offshore seismic facies, Central Andes.

RESUMEN. Arquitectura sísmica-estratigráfica de la Formación Camaná del Oligoceno-Plioceno, Antearco del sur de Perú (Provincia de Arequipa). La Cuenca Camaná-Mollendo es una depresión de margen activo en el sur de Perú, la cual es elongada en sentido NW-SE y se extendiende desde la cordillera de la Costa hasta la fosa Perú-Chile. Esta cuenca consiste en un sistema de graben y semigrábenes y está rellenada con rocas sedimentarias de edad Oligoceno a Plioceno, correspondientes a la Formación Camaná (deltaico y fluvial, $\sim 500 \mathrm{~m}$ de espesor). Una integración de datos provenientes de columnas estratigráficas, sísmica de reflexión 2D costa afuera, proveniencia sedimentaria, y geocronología de $\mathrm{U}-\mathrm{Pb}$ en zircones volcanoclásticos ayudó a elaborar un cuadro tectono-cronoestratigráfico de toda la Cuenca Camaná-Mollendo. Para llevar a cabo esta integración, en primer lugar se requirió reinterpretar geológicamente la data sísmica 2D costa afuera y resaltar las características estratigráficas más prominentes (i.e., superficies erosivas), las cuales son atribuibles a la Formación Camaná. Estas características lograron ser correlacionadas con las superficies erosivas definidas en la Formación Camaná costa adentro y dieron como resultado la siguiente división: (i) "Unidad CamA" de la Formación Camaná (deltas de grano grueso) y (ii) "Unidad CamB" de la Formación Camaná (depósitos fluviales). La Unidad CamA se subdividió en tres subunidades en base a discontinuidades estratigráficas menores y diferencias en su geometría depositacional (i.e., A1: Oligoceno; A2: Mioceno inferior; y A3: Mioceno medio). La Unidad CamA refleja geometría progradante (A1 y A2) y "onlapante" (A3). La Unidad CamB (Mioceno superior a Plioceno) comprende conglomerados fluviales e hiperpícnicos de alta energía. Cada una de estas unidades y subunidades se extienden costa afuera de Camaná y mantienen similares geometrías depositacionales y los mismos límites secuenciales. En los depósitos costa afuera, las subunidades A1 y A2 (Oligoceno a Mioceno Inferior) están agrupadas como "A1+A2" debido a que ambos muestran similares geometrías progradacionales y es difícil diferenciarlos. Un sistema regresivo $(R S T)$ representa estas subunidades. Estos depósitos alcanzan $\sim 2,5 \mathrm{~km}$ de espesor, y están intensamente afectados por fallas normales y lístricas asociados a geometrías depositacionales pinch-out. Los estratos de la subunidad A3 (Mioceno Medio) reflejan un sistema transgresivo (TST), y cubren toda la cuenca con sedimentos finos. La subunidad A3 alcanza $\sim 1 \mathrm{~km}$ de espesor, y se caracteriza por su geometría "onlapante", y menor proporción de tectónica sinsedimentaria. Finalmente, la depositación de la Unidad CamB (Mioceno Superior a Plioceno) ocurrió durante un nuevo episodio regresivo $(R S T)$, la cual se vuelve deltaica y progradacional costa afuera y está mucho menos afectada por fallas sinsedimentarias. Los límites estratigráficos entre "A1+A2" y A3, y entre A3 y CamB observados costa adentro se utilizan para diferenciar, correlacionar y predecir las principales geometrías depositacionales y sistemas depositacionales encadenados interpretados para los depósitos costa afuera. Los reflectores sísmicos de alta frecuencia representan tales límites y apoyan la subdivisión de la Formación Camaná costa afuera. Estos límites son además utilizados para definir depocentros a lo largo de la Cuenca CamanáMollendo, donde los depocentros más voluminosos están ubicados en las cercanías de los grandes valles (e.g., Planchada, Camaná y Punta de Bombón). Los depósitos de las subunidades "A1+A2" son considerados como un potencial reservorio de hidrocarburos debido a su alta tasa de sedimentación. Los depósitos de la subunidad A3 son transgresivos y considerados como una potencial roca sello. Estructuralmente, la Cuenca Camaná-Mollendo está compuesta por elementos estructurales propios de sistemas de grábenes y semi-grábenes, los cuales están orientados preferencialmente $\sim \mathrm{NW}$-SE (orientación andina).

Palabras clave: Cuenca Camaná-Mollendo, Cenozoico, Estratigrafía secuencial, Facies sísmicas costa afuera, Andes Centrales.

\section{Introduction}

Since the 1980's, models on stratigraphy of sequences for Cenozoic deposits in southern Peruvian forearc were based on Cenozoic eustatic cycles (e.g., Macharé et al., 1986; DeVries, 1998). However, in an active and convergent tectonic context like the subduction of the Nazca Plate beneath South America, sedimentary evidences of uplift and crustal thickening are rather evident and expected to occur in Central Andes (e.g., Jordan et al., 1983; Mahlburg-Kay, 2005; Oncken et al., 2006). In this context, sedimentary stacking patterns and sedimentation style in an active tectonic context depend largely on tectonic factors such as subsidence and/or uplift more than purely eustatic 
influences (e.g., Williams, 1993; Hardenbol et al., 1998). Thus, we consider deposits of the Cenozoic Camaná Formation in the forearc of southern Perú (see geology in Fig. 1A) as the best candidates to study the interplay and dominancy of the factors that control forearc geodynamics and resulting sediment dispersal in southern Peruvian forearc (cf. Alván and von Eynatten, 2014). Accordingly, we use such arguments to predict sedimentary facies in the offshore deposits, where there is neither well-core nor sample, only geophysical data.

The main objective of this manuscript is to explain the chronostratigraphic and structural organization of the Cenozoic Camaná Formation in onshore and offshore of southern Perú, and explain the origin and location of sedimentary depocentres that are attractive for oil exploration. To accomplish these goals, we needed to integrate new interpreted seismic data ( $647 \mathrm{~km}$ of $2 \mathrm{D}$ seismic profiles) with previous studies on sedimentary provenance (including heavy mineral analysis and $\mathrm{U}-\mathrm{Pb}$ geochronology on detrital zircons), previous sedimentary facies analysis, and sequence stratigraphy (e.g., Vega, 2002; Alván and von Eynatten, 2014; Alván et al., 2015). The results will define the chrono-stratigraphic and structural framework of the Camaná-Mollendo Basin and predict sedimentary extension in the offshore of Camaná.

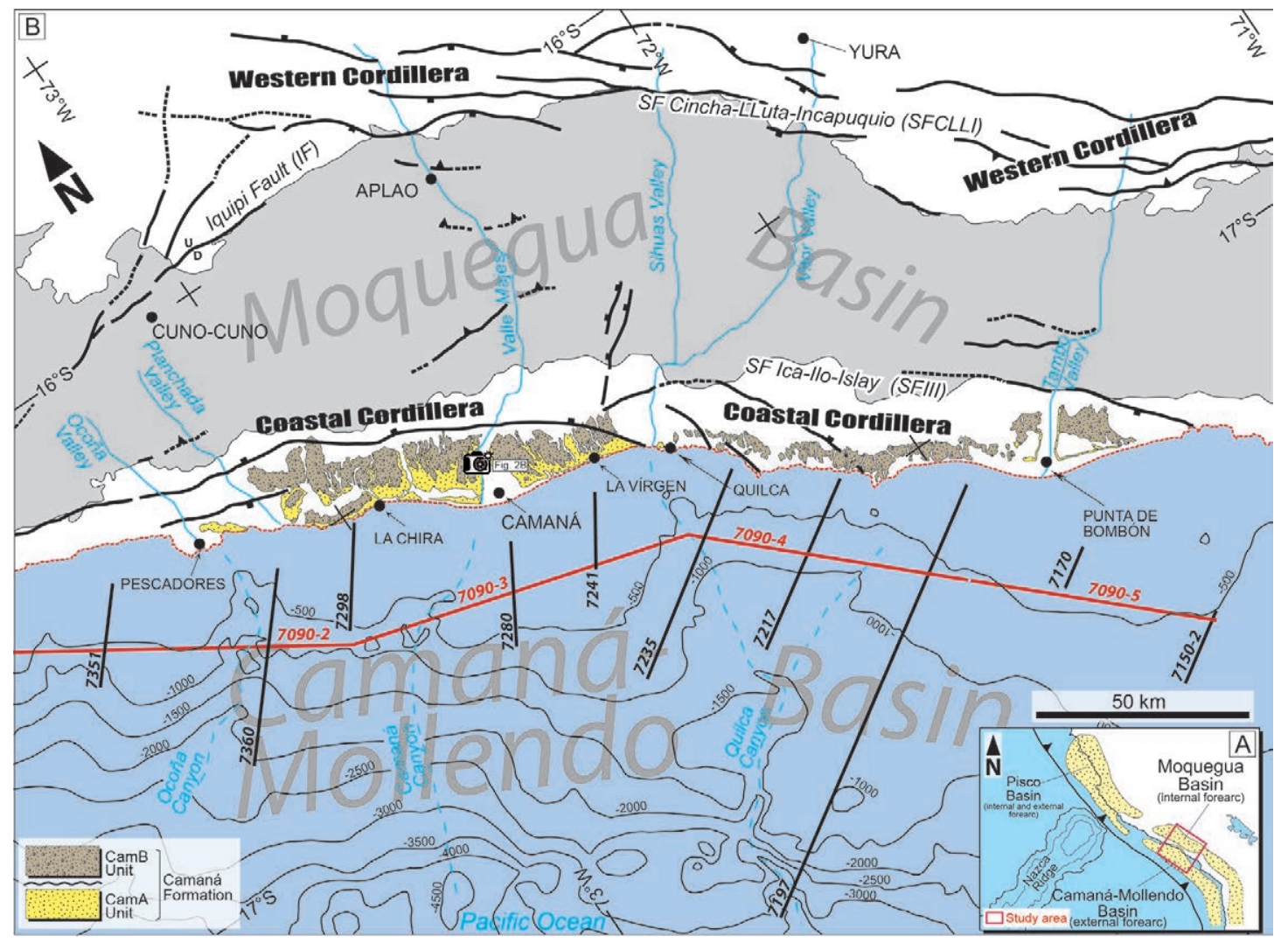

FIG. 1. Simplified geological map of the study area (Province of Camaná, Arequipa Region) (after Pecho and Morales, 1969; León et al., 20001). A. Inset map shows position of the Pisco, Moquegua and Camaná-Mollendo Basins according to Perupetro, 2003²); B. Map showing the position of seismic lines. In offshore, black lines represent $\sim \mathrm{NE}-\mathrm{SW}$ data roughly perpendicular to coast line, and red lines indicate $\sim \mathrm{NW}$-SE data, roughly parallel to the coast.

${ }^{1}$ León, W.; Palacios, O.; Torres, V. 2000. Sinopsis sobre la revisión de la Geología de los Cuadrángulos de Atico (33o), Ocoña (33p), Camaná (34q), La Yesera (33q), Aplao (33r), Mollendo (34r). Dirección de Geología Regional, Instituto Geológico Minero y Metalúrgico (INGEMMET), Reporte Interno: 8 p. Perú.

${ }^{2}$ Perupetro, 2003. Peruvian Petroleum, A Renewed exploration opportunity. Lima, Perú, Report of Perupetro: 159 p. 


\section{Geological setting}

Central Andean geodynamics are widely characterized by alternating episodes of differential deformation, shortening, crustal thickening, uplift and resulting subsidence (Jordan et al., 1983; Isacks, 1988; Ellison et al., 1989; Mahlburg-Kay et al., 2005; Oncken et al., 2006), which have influenced on generation of sediments since at least Eocene (e.g., Macharé et al., 1986; von Huene and Lallemand, 1990; Scheuber et al., 2006). For instance, the most relevant and voluminous sedimentary deposits of Cenozoic age are located in the Altiplano and in the forearc of southern Perú (Marocco and Noblet, 1990).

Southern Peruvian forearc comprises numerous elongated asymmetric structural depressions that are filled with Cenozoic marine and continental sediments (i.e., Pisco, Camaná, and Moquegua Basins, Fig. 1A), which are parallel to the general striking of the southern Peruvian Andes margin ( NW-SE, Sébrier et al., 1984; Palacios, 1995; Perupetro, 2003²). Such deposits crop out between the Western Cordillera and the Peruvian trench, lying above the Proterozoic and Paleozoic basements (e.g., Arequipa Massif, San Nicolás Batholith, Mitu Group and Ambo Group, Pecho and Morales, 1969). Geomorphologically, the most relevant depressions in the forearc of Southern Perú cited in this manuscript (i.e., Camaná-Mollendo Basin and Moquegua Basin) are bounded by two voluminous cordilleras. One of these cordilleras is the Coastal Cordillera, which divides the CamanáMollendo Basin and the Moquegua Basin (Pecho and Morales, 1969; Sébrier et al., 1984; Palacios and Chacón, 1989) (Fig. 1B).

Rocks of the Coastal Cordillera are affected by intense normal faulting defined as a complex of normal displacements of the Ica-Ilo-Islay Fault System (IIIFS), while the Western Cordillera is affected by a complex of faults with similar behavior termed Cincha-Lluta-Incapuquio Fault System (CLLIFS, Jacay et al., 2002; Acosta et al., 2012) (black lines in Fig. 1B).

Moquegua Basin is the easternmost basin and consists of a $\sim$ NW-SE elongated depression located in the internal forearc (or Central Depression) and it is filled with continental sediments (lacustrine and fluvial) of the Cenozoic Moquegua Group (Pecho and Morales, 1969; Marocco et al., 1985). On the western side, the external forearc (coastal range) comprises sedimentary rocks of the Camaná
Formation (Steinmann, 1930; Rivera, 1950), which is the topic of this manuscript. The Camaná Formation crops out between Pescadores $\left(16^{\circ} 25^{\prime} \mathrm{S}\right)$ and Punta del Bombón ( $\left(7^{\circ} 15^{\prime} \mathrm{S}\right)$, showing up to $\sim 500 \mathrm{~m}$ thick coarse-grained deltas and fluvial deposits of Cenozoic age (Vega, 2002; Alván and von Eynatten, 2014; Alván et al., 2015) (Fig. 1B). These sediments form also a $\sim$ NW-SE elongated sedimentary deposit which onlaps the Proterozoic and Paleozoic basements in onshore, and face the Pacific Ocean.

According to Perupetro (2003) $)^{2}$ the "Mollendo Basin" is located in the offshore of the Arequipa Region, and possibly extends onto offshore as prolongation of the Camaná Basin known in onshore (Fig. 1A). Here, we consider adequate the use of the term "Camaná-Mollendo Basin" to group the both Camaná and Mollendo Basins, the term "Camaná Basin fill" for deposits that are located in onshore, "Mollendo Basin fill" as the deposits that are in the offshore, and "Camaná-Mollendo Basin fill" to refer to both onshore and offshore deposits of the Camaná Formation.

\subsection{Chronostratigraphic architecture of the Camaná Basin onshore}

Camaná Formation is a lithostratigraphic unit composed of marine and fluvial sediments (Steinmann, 1930; Rivera, 1950). Later studies on sedimentology of the Camaná Formation such as Vega (2002) proposed a chronology between Oligocene and Middle Miocene, on the basis of vertebrate and microfauna paleontology (cf. Tsuchi et al., 1990; Ibaraki, 1992; Apolín, 2001). Sempere et al. (2004) extended the age of Camaná Formation as old as Eocene, stating that its internal depositional geometry is due to its deltaic nature. On the basis of facies analysis, Alván and von Eynatten (2014) redefined the Camaná Formation as a complex of coarse-grained deltas and fluvial marginal conglomerates. These authors divided Camaná Formation into two main depositional units, (i) CamA Unit and (ii) CamB Unit, where CamA is further subdivided into subunits A1, A2, and A3 (Fig. 2). Alván et al. (2015) dated sediments of Camaná Formation using U-Pb on volcanoclastic zircons (see red numbers in Fig, 2) assuming that most of Cenozoic volcanism in Central Andes ( $\sim 30$ $4 \mathrm{Ma}$ ) occurred simultaneous to fluvial and marine sedimentation in southern Peruvian forearc (e.g., Marocco and Noblet, 1990) and can resemble closely 

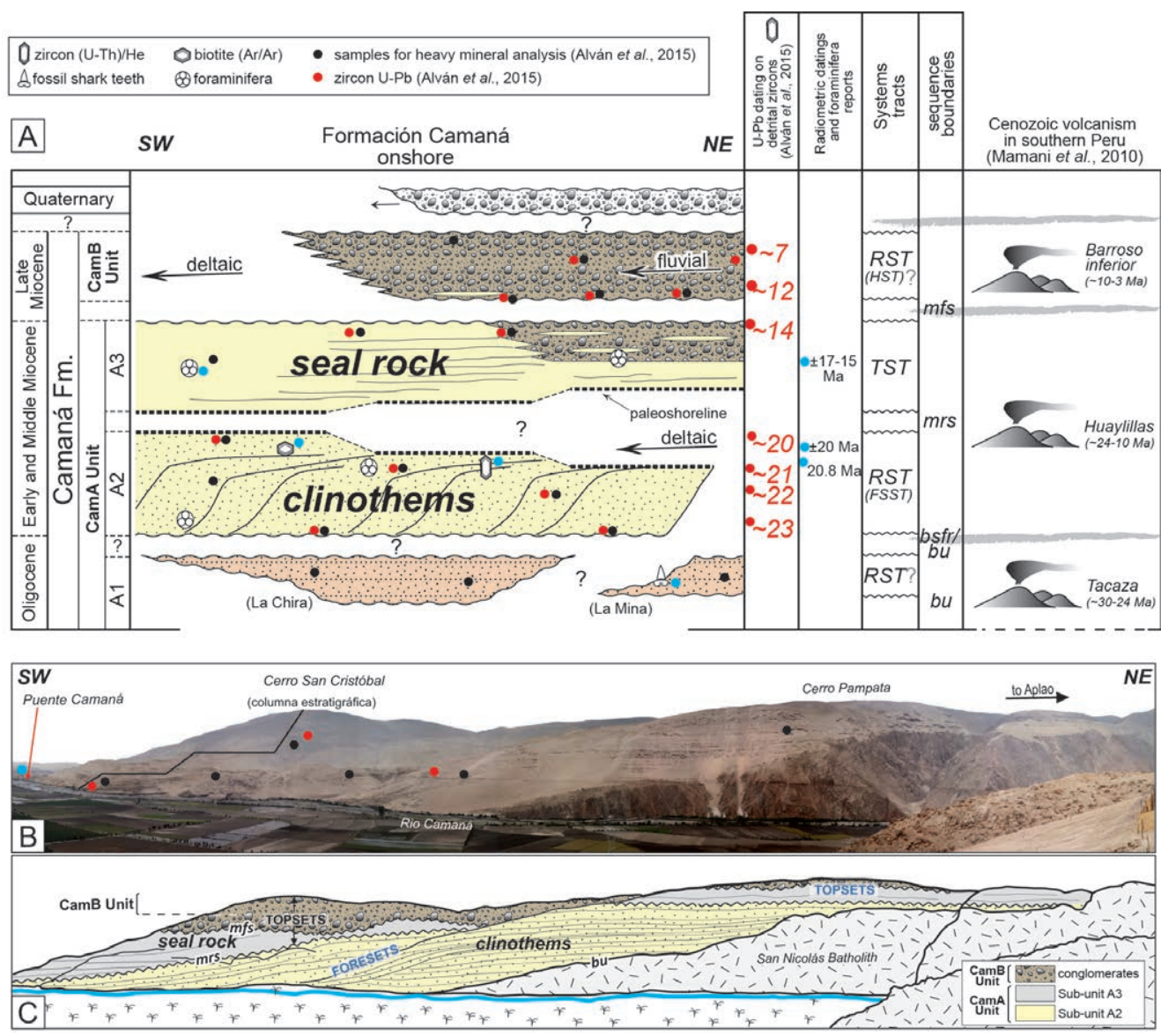

FIG. 2. Chronostratigraphic chart of the Camaná Formation (onshore) and stratotype of Camaná Formation (Puente Camaná). A. according to Alván and von Eynatten (2014), subunit A1 consists of mouth bars and distributary channels tentatively assigned to the Late Oligocene. Subunit A2 consists of progradational clinothems formed during a falling stage systems tract (FSST) in Early Miocene. We consider useful to group "A1+A2" and consider them as Oligocene to Early Miocene in age (as Alván et al., 2015). Subunit A3 consists of onlapping deltaic sandstones deposited during a transgressive systems tract (TST), Middle Miocene. CamB is deposited during a regressive systems tract (RST) (or very possibly a highstand systems tract, HST) in Late Miocene to Pliocene; B. samples acquired for U-Pb dating on detrital zircons presented by Alván et al. (2015). C. depositional geometries of within the Cenozoic Camaná Formation. Abbreviations: $\mathbf{b u}=$ basal unconformity, $\mathbf{b s f r}=$ basal surface of forced regression, $\mathbf{m r s}=$ maximum regressive surface, $\mathbf{m f s}=$ =maximum flooding surface.

sedimentation ages (cf. Bowring and Schmitz, 2003; von Eynatten and Dunkl, 2012).

According to Alván and von Eynatten (2014), reddish sandstones of subunit A1 are the basal strata of Camaná Formation and consist of mouth bar deposits and distributary deltaic channels. The chronostratigraphic problem with this subunit is the lack of Cenozoic ages, according to Alván et al. (2015); nonetheless, given the onset of intense volcanism of the $\sim 24-10$ Ma Huaylillas volcanic arc in Central Andes reported by Wörner et al. (2000) and Mamani et al. (2010), which are the equivalents of the overlying subunit
A2, a correlation between subunit A1 (of Camaná Formation) and $\sim 30$ Ma subunit MoqC1 (of Moquegua Group) is consistent. Furthermore, similarities in sediment composition between both subunits proposed by Alván et al. (2015) suggest that both correspond to a unique time line (Oligocene).

Subunit A2 consists of coarse-grained deltaic deposits arranged in progradational clinothems (SWoriented), while in contrast, the overlying subunit A3 consists of delta front to prodelta deposits arranged in onlapping geometry. Zircon youngest $\mathrm{U}-\mathrm{Pb}$ age components on volcanoclastic zircons within subunits 
A2 and A3 yield ages of $\sim 23, \sim 21, \sim 20$, and $\sim 14 \mathrm{Ma}$ (see red numbers in Fig. 2), spanning the Early Miocene to early Middle Miocene ( $~ 9$ Myr, Alván et al., 2015). On top of Camaná Formation, CamB Unit consists of a $\sim 200 \mathrm{~m}$-thick stacking of fluvial conglomerates dated close to Late Miocene to Pliocene, according to Alván et al. (2015). Once established chrono-stratigraphic framework of the Camaná Formation in onshore, erosional surfaces in-between each depositional subunit (i.e., "A1+A2"-A3 and $\mathrm{A} 3-\mathrm{CamB}$ ) allow to mark stratigraphic boundaries in terms of stratigraphy of sequences (such as "bu", "bsfr", "mrs" and " $m f s$ " in Fig. 2), and are useful to start formulating consistent arguments for stratigraphic correlations to offshore deposits and predictions.

\section{Morphology of the sea flor in the offshore of Camaná}

The sea flor of the offshore in front of Camaná shows a smooth downslope below $\sim 900 \mathrm{~m}$ depth, showing gradients of $\sim 5^{\circ}$ in average and forms sedimentary complexes that extend from the shelf down to the slope. There, three submarine canyons roughly $\sim \mathrm{NE}-\mathrm{SW}$-oriented i.e., Ocoña, Camaná, and Quilca Canyons (blue dotted lines in Fig. 1B) and according to satelital images, several $\sim \mathrm{NW}$-SE-oriented fault scarps are prominent (see dotted red lines in Figs. 3 and 4) (cf. Hagen, 1993). Ocoña Canyon extends up to $\sim 1,700 \mathrm{~m}$ depth, while Camaná Canyon up to $\sim 4,000 \mathrm{~m}$ depth, and Quilca Canyon up to $\sim 3,000 \mathrm{~m}$ depth. Fault scarps are mostly $\sim \mathrm{NW}-\mathrm{SE}$ oriented, and are visible along the sea floor up to the offshore of northern Chile (von Huene et al., 1996). If we prolongate alignments of the submarine canyons back to onshore, we observe that the thickest stackings of the Camaná Formation coincides with the river mouths of the large valleys at La Chira (16 $30^{\prime}$ S), Camaná (16 38' S), La Virgen (16 $43^{\prime}$ S), and Punta de Bombón (17 ${ }^{\circ} 15^{\prime}$ S) (Pecho and Morales, 1969; Sempere et al., 2004; Roperch et al., 2006).

\section{Sequence stratigraphy of the Camaná Formation}

Alván and von Eynatten (2014) presented a consistent sequence stratigraphic model for the Camaná Formation (left side in Fig. 2), which suggests contrasts in relation to the global sea-level fluctuations. This definition allowed highlighting influence of tectonics for each subdivision of the Camaná Formation. Given a chronostratigraphic framework of the Camaná Formation (Alván et al., 2015), it is possible to compare the age of the depositional events with the global eustatic chart presented by Haq et al. (1987) y Hardenbol et al. (1998). The results permited highlight the influence of tectonics on sedimentation for each unit of the Camaná Formation. Such influences are reflected very possible in vertical displacements along the Ica-Ilo-Islay Fault System (IIIFS, see Fig. 1B).

\subsection{Stratigraphy of sequences in subunit A2 of Camaná Formation}

For instance, clinothems of the subunit A2 show a pronounced progradational-stacking pattern, where according to Alván and von Eynatten (2014) sediment input strongly exceeded accommodation space, enough to produce progradational geometry (e.g., Catuneanu, 2002). Subunit A2 is bounded at the base by a basal surface of forced regression (bsfr) if lies above deposits of subunit A1 (e.g., La Chira, north Camaná) and lies above a basal unconformity $(b u)$, if these deposits lie directly above the basement (e.g., Puente Camaná, Fig. 2B). Subunit A2 is bounded on top by a maximum regressive surface (mrs) (see left side in Fig. 2). Strata of subunit A2 suggest a regressive systems tract (RST) occurred during Early Miocene (or even since Oligocene). Such regression may even have been forced (falling stage systems tract) (FSST), which is also driven by a drastic or rapid relative sea-level fall (e.g., Catuneanu, 2002).

\subsection{Stratigraphy of sequences in subunit $A 3$ of Camaná Formation}

A change on depostional geometry occurs above mrs because during deposition of the subunit A3, relative sea-level rise outpaced sedimentation rates and resulted in onlapping deposition. This deposition is considered to have occurred during a transgressive systems tract between late Early Miocene and early Middle Miocene ( $<20$ to $\sim 14 \mathrm{Ma}$ ). Such relative seal-level rise continued until the completion of the deposition of the subunit A3. Subunit A3 is bounded on top by a notorious maximum flooding surface ( $\mathrm{m} f \mathrm{~s}$ ). CamB Unit occurs in onshore as fluvial prograda- 
tional conglomerates that presumably have formed during a regression (probably a highstand systems tract). However, CamB unit extends to offshore as a deltaic progradation (see Section 5.2.4).

Haq et al. (1987) described $2^{\text {nd }}$ order eustatic cycles (sequence cycles ranging between 2 and 50 Ma) showing a transgressive major cycle since the Late Oligocene (Chattian) to Early Miocene, which is apparently chronologically comparable to subunit A2 of CamA unit. This transgressive curve strongly contrasts with the regressive trend of subunits $\mathrm{A} 1$ and A2. Hence, a striking tectonic uplift of the Coastal Cordillera is deduced and outpaces the global sea-level rise. However, the later transgressive deposition of subunit A3 occurred during the late Early Miocene to early Middle Miocene is consistent with the general eustatic rise reported by Haq et al. (1987). However, during deposition of the subunit A3, minor uplift affecting some area of the Western Cordillera and/or the Pacific Piedmont is thought to have occurred during this period, which is reflected in conglomerates within A3 (left side of Fig. 2) marking the onset of a shift in sediment provenance. Hence, minor and probably local pulses of uplift have also affected the Camaná-Mollendo Basin during the Middle Miocene eustatic rise.

\subsection{Stratigraphy of sequences in CamB unit of Camaná Formation}

Since the late Middle Miocene to Pleistocene, Haq et al. (1987) proposed regressive cycles with short and minor transgressive stages. This is consistent with deposition of CamB; however, deposition of CamB reflects rapid uplift in the hinterland (Western Cordillera and/or Pacific Piedmont, e.g., Schildgen et al., 2009; Alván et al., 2015), and they have influenced sedimentation more than eustatic or climate-driven factors. Once established the stratigraphic sequence model, we proceed to extend the bounding surfaces of the Camaná Formation onto its offshore equivalents.

On the other hand, subunit A1 cannot be attributed to a specific systems tract itself because of its limited exposures (up to $10 \mathrm{~m}$ thick at Playa La Chira). However, subunit A1 shares some facies features with the overlying subunit A2 and they both can be tentatively considered within the same depositional trend (progradation), which are considered here as the grouping "A1+A2" (regressive systems tract).

\section{Geological reinterpretation of offshore seismic data in front of Camaná}

We agree with Vega (2002), who stated that most of the seismic data from offshore deposits of Camaná are widely affected by grabens and half-graben structures, typically with sinsedimentary normal faulting. However, this study highlight several features that points the recognition of sedimentary subunits of the Camaná Formation and their respective stratigraphic boundaries (erosive surfaces), which are crucial for predictions of potential reservoirs. Figures 3, 4, 5 and 6 show stratigraphic boundaries proposed in this study.

\subsection{Methodology}

a. The data used to study the Mollendo Basin fill have been acquired from seismic campaigns by the Compagnie Generale de Geophysique (CGG) for Perupetro in 1982, using air canyons for shooting with a source depth of 5,5 seconds (marine seismic reflection). Here we present new and improved reinterpretations of the seismic information of this basin fill (after Vega, 2002; Perupetro, 2003²). Despite acquisition of seismic data was accomplished with 30 year-old technology, the data responded to the identification of a "back stop" or high-frequency reflectors, which are considered here as major bounding surfaces that exist within the strata of Camaná Formation. The seafloor bathymetry of Camaná offshore was downloaded from http:// maps.ngdc.noaa.gov/viewers/multibeam/ (National Oceanic and Atmospheric Administration, NOAA) (last visit 20/10/2016), and an approximation of the relation between TWT (two way time) and deepness is suggested (up to $5.000 \mathrm{~m}$ depth). We managed interpreting our seismic data by characterizing and recognizing the most prominent features that can resemble deltaic geometry, and differentiate its differents stacking patterns, besides its bounding surfaces. The seismic interpretation has been accomplished by analysing two groups of seismic lines (see red and black lines in offshore, Fig. 1B). The first group consists of ten seismic lines $\sim \mathrm{NE}$ SW-oriented, roughly perpendicular to the shoreline and parallel to the orientation of sediment influx. These lines are (1) 7360 (Ocoña, Fig. 3A), 42 km lenght, (2) 7298 (Playa La Chira, Fig. 3B), 22 km lenght; (3) 7280 (Camaná, Fig. 3C), 20 km lenght; 

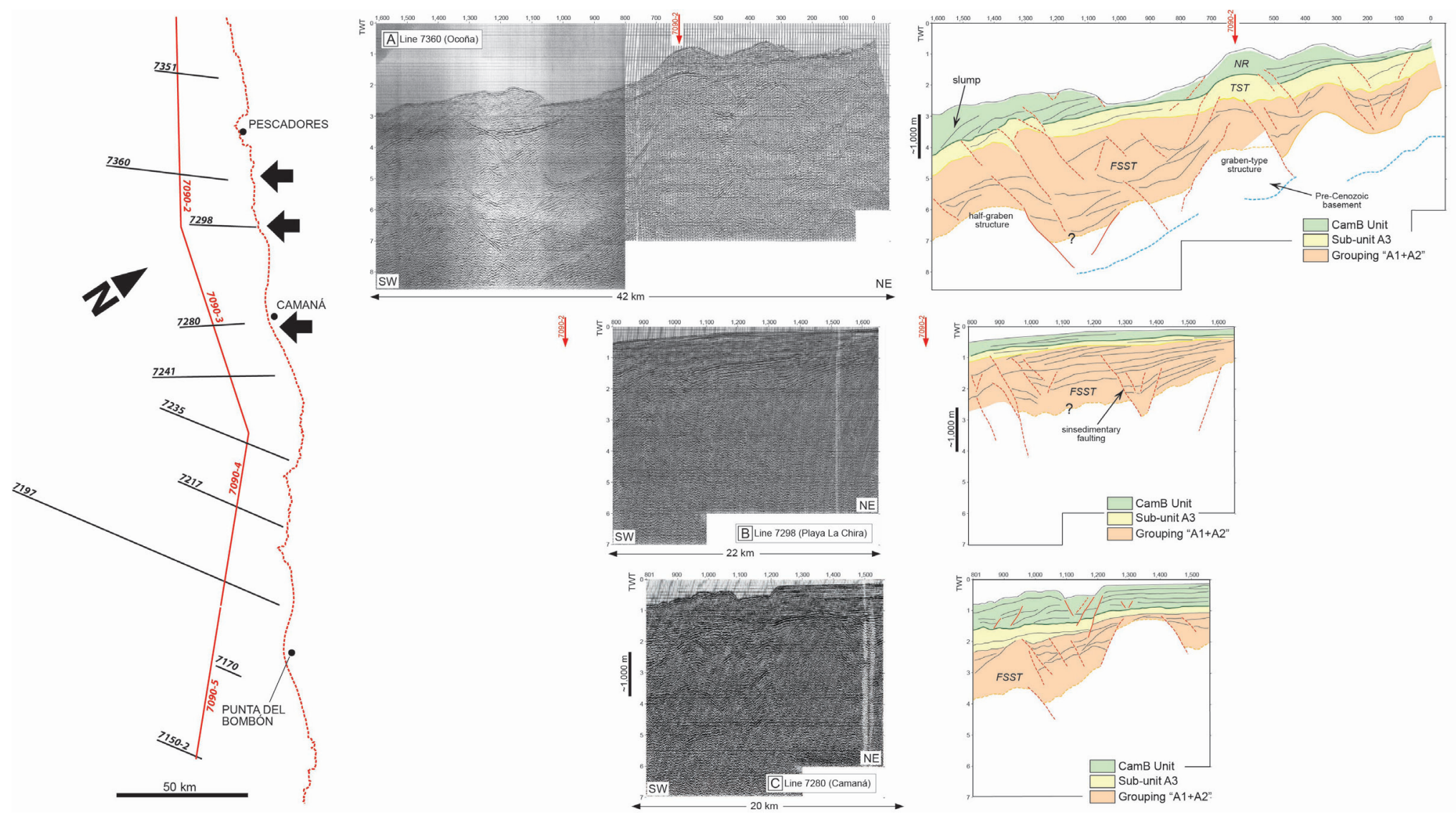

FIG. 3. Seismic lines NE-SW-oriented (black lines). A. Ocoña (7360); B. Playa La Chira (7298) and C. Camaná (7280). It is observable several structures inferred as faulting, which are indicated in red lines. Contact between Pre-Cenozoic basement and Camaná Formation is not clear; however, their boundaries are interpreted preliminarily above dotted light blue lines. 

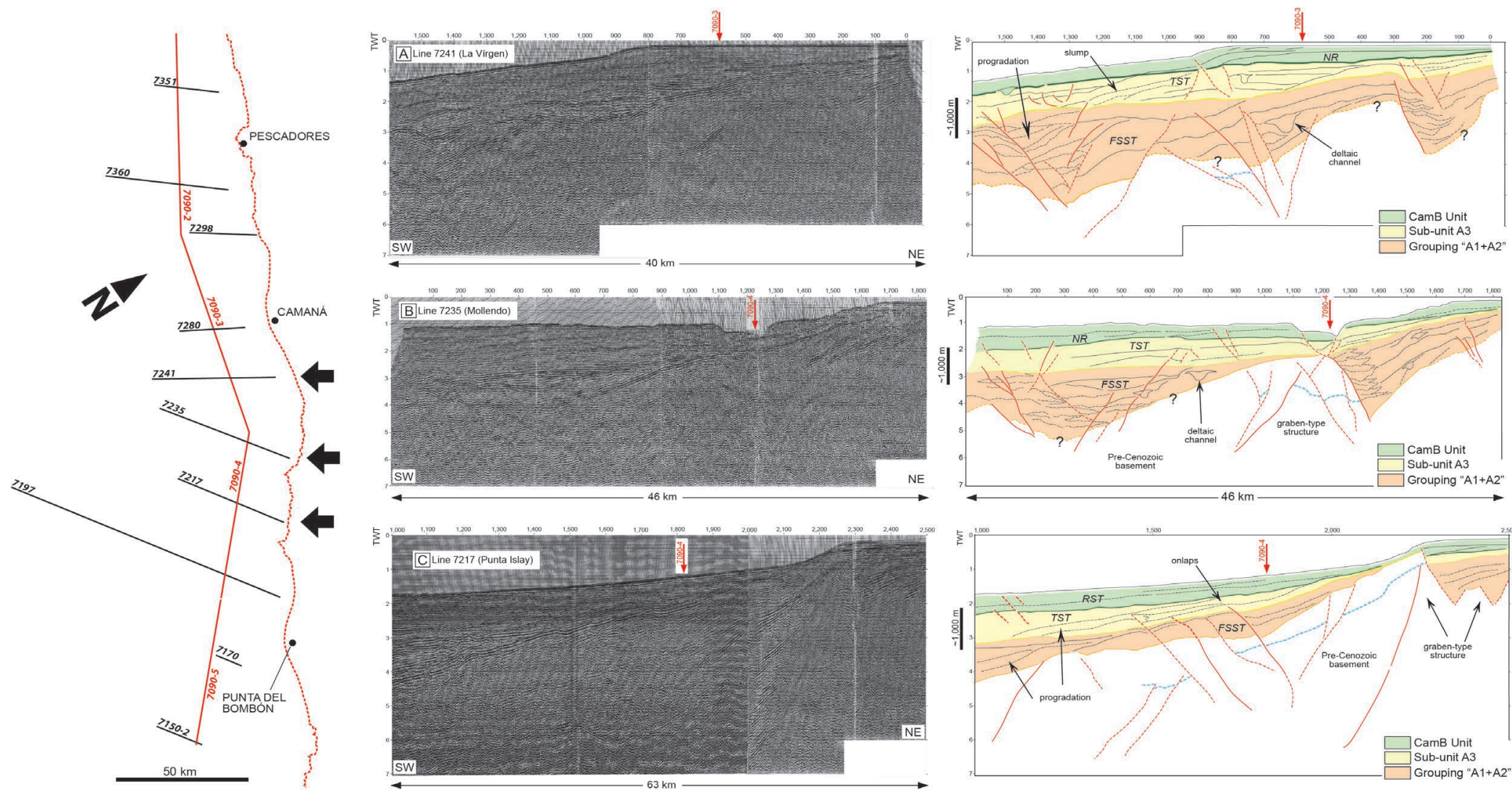

FIG. 4. Seismic lines NE-SW-oriented (black lines). A. La Virgen 7241), B. Mollendo (7235) and C. Punta Islay (7217). It is observable several structures inferred as faulting, which are highlighted in red lines. Contact between Pre-Cenozoic basement and Camaná Formation is not clear; however, their boundaries are interpreted preliminarily above dotted light blue lines. 


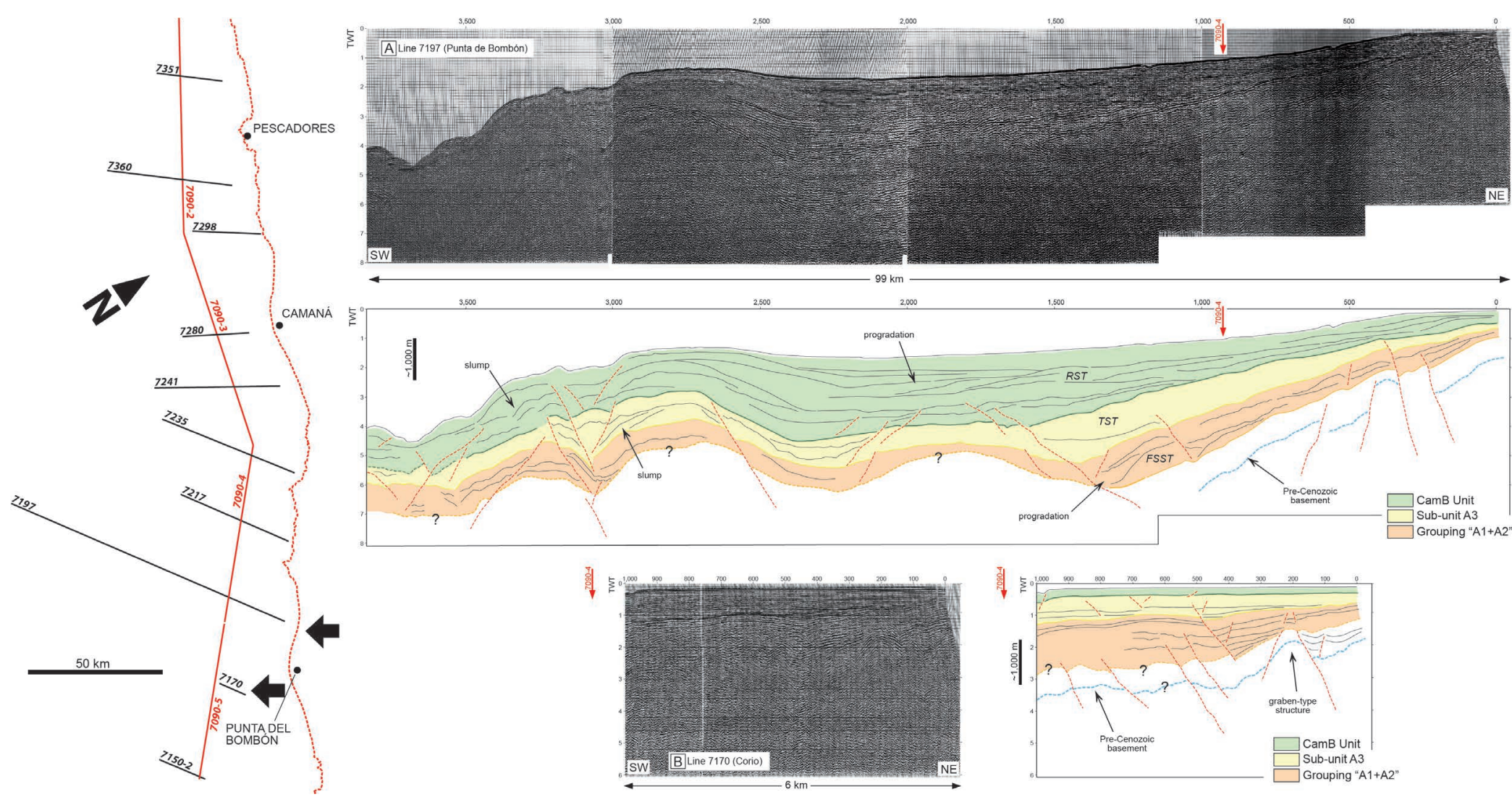

FIG. 5. Seismic lines NE-SW-oriented (black lines). A. Punta de Bombón (7197) and B. Corio (7170). It is observable several structures inferred as faulting, which are highlighted in red lines. Contact between Pre-Cenozoic basement and Camaná Formation is not clear; however, their boundaries are interpreted preliminarily above dotted light blue lines. 
(4) 7241 (La Virgen, Fig. 4A), 40 km lenght; (5) 7235 (Mollendo, Fig. 4B), 46 km lenght; (6) 7217 (Punta Islay, Fig. 4C), 63 km lenght; (7) 7197 (Punta de Bombón, Fig. 5A), 99 km lenght; (8) Corio (7170, Fig. 5B), $\sim 6 \mathrm{~km}$ lenght; and adittionally lines (9) 7370 (Atico), $19 \mathrm{~km}$ lenght, (10) 7351 (Cerro de Arena), $20 \mathrm{~km}$ lenght, and (11) 7150-2 (Guardianía), 16 km lenght. In total, this study comprises $\sim 393 \mathrm{~km}$ lenght of seismic lines $\sim \mathrm{NE}-\mathrm{SW}$-oriented.

b. The second group consists of three seismic lines $\sim$ NW-SE-oriented, parallel to the actual shoreline and the cordilleras in the southern Peruvian forearc. These lines are (1) 7090-2 (Atico-Ocoña, Fig. 6A), 60 km length, (2) 7090-3 (La ChiraQuilca, Fig. 6B), $77 \mathrm{~m}$ length, and (3) 7090-4 (Quebrada Honda-Punta de Bombón, Fig. 6C), $\sim 47 \mathrm{~km}$ length. In total, there is $\sim 184 \mathrm{~km}$ length of $\sim$ NW-SE-oriented seismic lines.

Because seismic lines are the graphic representation of the response of different structural features and sedimentary stacking when a seismic wave passes (Vail et al., 1977), we consider that the geometry of the end of the seismic reflectors is a tool to identify geometries, i.e., truncations, onlaps, downlaps, toplaps, and offlaps (e.g., Catuneanu 2002; Catuneanu et al., 2009). Thus, our correlation begins with the tracing of high-frequency reflectors considered as bounding surfaces, which divide the depositional units (i) "A1+A2", (ii) A3, and (iii) CamB Unit. We use the term "A1+A2" (pink deposits in figures 3, 4, 5, and 6) because they both show similar sedimentary facies and because both deposits were accumulated during a regressive systems tract (Alván and von Eynatten, 2014). Once defined stratigraphic boundaries in offshore deposits of the Camaná Formation, we produce information on stratigraphic thickness of the (i) NW-SE-oriented and (ii) NE-SW-oriented, for each subunit. All data posses coordinates and stratigraphic thickness and were plotted in ArcGIS (versión 10) by using TIN (triangulated irregular nets). The results permited to define depocentres and relate their existence to the presence of main families of faults (see orange circles in Fig. 7).

\subsection{Description of seismic facies}

\subsubsection{Basement}

The basement observed in the onshore of Camaná is composed of metamorphic rocks of the Arequipa
Massif (Proterozoic), igneous rocks of the San Nicolas Batholith (Ordovician), and sedimentary rocks the Ambo and Mitu Groups (Carboniferous) (Pecho and Morales, 1969). However, in offshore it is difficult to observe convincing seismic facies or reflectors that permit identify or even discriminate them, or recognize additional basements. Nonetheless, some reflectors show seismic facies similar to a crystalline basement and stratal geometry with truncated terminations (for instance, Mesozoic and/ or Paleozoic strata in line 7360 , figure $3 \mathrm{~A}$, and in line 7217 , e.g., figure 4C). If we cross information of faults among seismic lines NW-SE- and NE-SWoriented, we observe that normal faulting shows aparent $\sim \mathrm{SW}$ and/or $\sim \mathrm{NE}$ direction of convergence (synthetic and antithetic components). On the other hand, lines 7090-2, 7090-3, and 7090-4 shown in figure 6 (parallel to the coast), show that basement rocks are also affected by $\sim \mathrm{NW}-\mathrm{SE}$ normal faulting, which presumably controlled formation of stratigraphic depocenters of the Camaná Formation (see for instance, orange polygons in Fig. 7). We consider such $\sim \mathrm{NW}$-SE-oriented and $\sim \mathrm{NE}$-SW-oriented faults as components of graben-type system, which are also thought to form basement highs (Figs. 3a and 4b).

\subsection{2. “ $A 1+A 2$ ”: progradational deposits}

Subunits A1 and A2 ("A1+A2") (light orange deposits in figures 3, 4, 5 and 6) overlie the PreCenozoic basement of the Camaná-Mollendo Basin above a basal unconformity (bu). Seismic lines $\sim$ NE-SW-oriented show that deposits of A1+A2 seems progradational clinothems with several filled channels showing stratal terminations such as offlaps and downlaps oriented to $\sim \mathrm{SW}$ (see orange deposits in figures $3 \mathrm{~A}$ and $3 \mathrm{~B}$ ). The thickest sedimentary stackings are observed in lines 7280 (Camaná, Fig. 3C), 7241 (La Virgen, Fig. 4A), and 7197 (Punta de Bombón, up to $\sim 3 \mathrm{~km}$ thick, figure $5 \mathrm{~A}$ ). Abundant normal faulting showing an apparently $\sim \mathrm{NW}$-SE orientation appears as growth faulting (listric), and they are typically observed in deposits of $\mathrm{A} 1+\mathrm{A} 2$ (red continued and dotted lines in orange deposits of figures 3, 4, 5 and 6). Stratal thickness is higher close to the fault plane, and pinches out laterally (e.g., the vicinity of the Ocoña, Quilca, and Punta de Bombón submarine canyons, and Playa La Chira (see left side of the seismic line 7090-3, figure 6B). This geometric feature suggests rapid filling of sediments and active tectonics. 


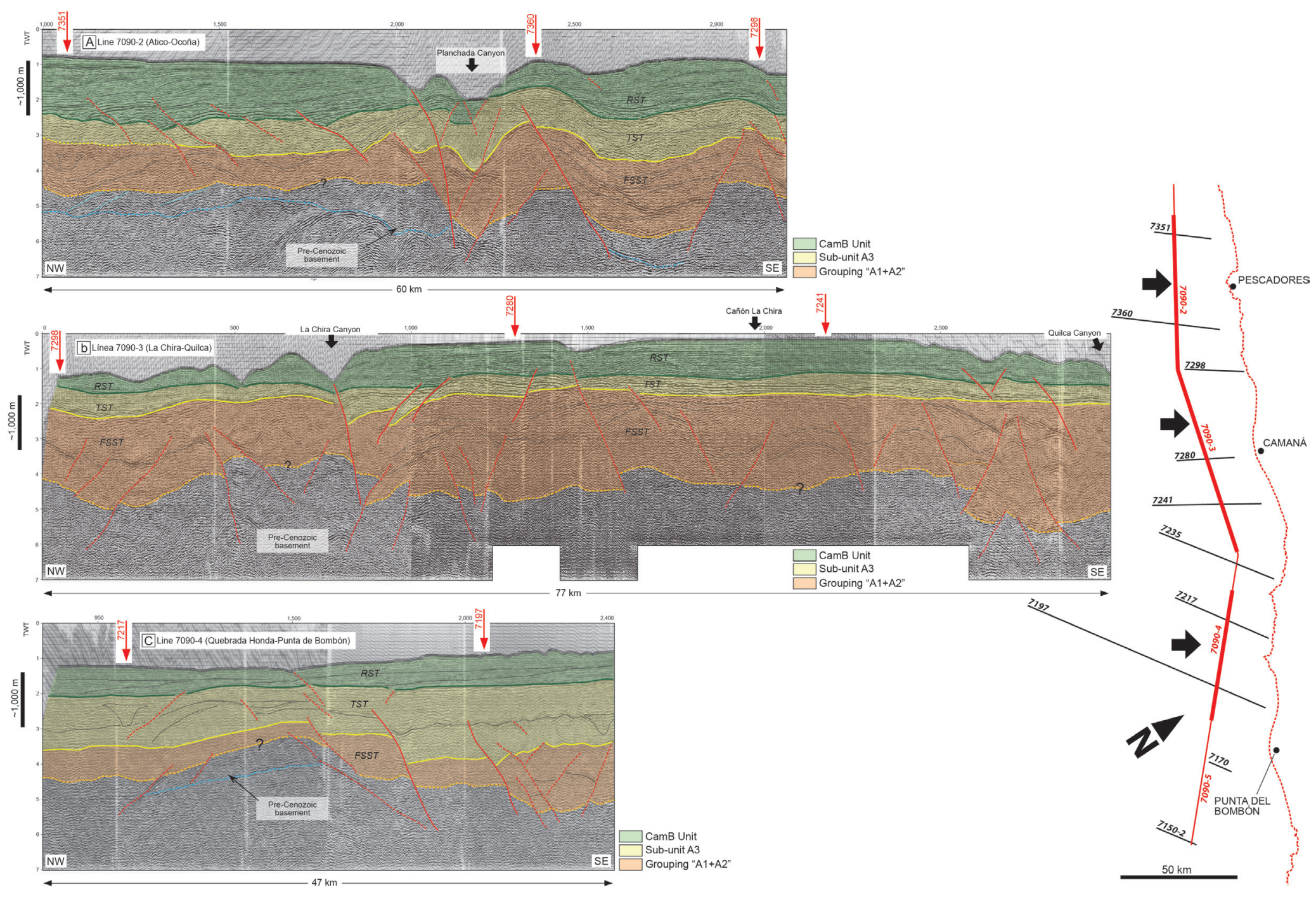

FIG. 6. Seismic lines NE-SW-oriented (red lines). A. 7090-2 (Atico-Ocoña), B. 7090-3 (La Chira- Quilca), and C. $7090-4$ (Quebrada Honda-Punta de Bombón). It is observable several structures inferred as faulting, which are highlighted in red lines. It is not possible to differentiate any type of basement, neither stratified nor crystalline. 


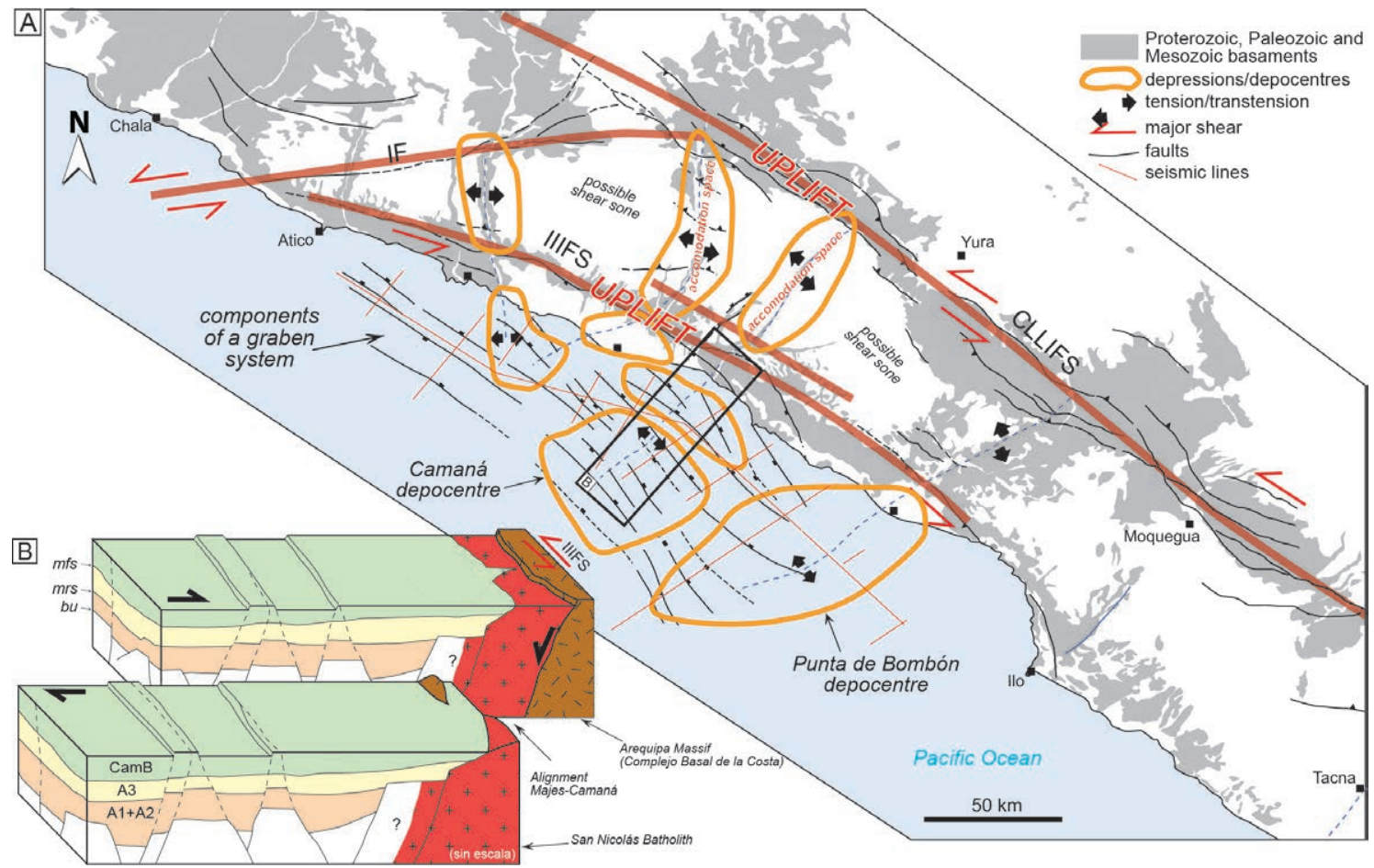

FIG. 7. Structural style proposed for the Camaná Basin at present day. A. The sediment fill of Camaná Basin was controlled by structural components $\sim \mathrm{NW}$-SE-oriented defined as graben and half-graben complex, which are typical of an extensional tectonic regime. The geodynamic evolution of Camaná-Mollendo Basin is related to uplift processes of basin borders and tectonic subsidence in its interior. See depocentres highlighted in orange polygons; B. Schematic configuration of deltaic deposits of Camaná offshore.

Deposits of "A1+A2" differ in stratal geometry to those of overlying subunit A3, and an erosive surface considered here as a maximum flooding surface (mrs) marks a disivion between these deposits by means of a high frequency reflector. Such boundaries are interpreted when observing lines $\sim \mathrm{NE}-\mathrm{SW}$-oriented. When comparing density of faulting in deposits of $\mathrm{A} 1+\mathrm{A} 2$ to faulting observed in deposits of overlying $\mathrm{A} 3$, it is possible to define that deposits of $\mathrm{A} 1+\mathrm{A} 2$ are the most tectonically affected deposits of the Camaná Formation. As appears, the main set of faulting is very possibly to be arranged rougly parallel to the actual shoreline (thin black lines in Fig. 8) and second group of fauting is roughly parallel to the $\sim \mathrm{NE}-\mathrm{SW}$ valleys and submarine canyons that are observed in forearc. Almost all of these faults are normal, and they are inferred as components of $\sim \mathrm{NW}$-SE-oriented graben-type structures inherited from the basement (see line 7235 of Mollendo in figure 4B, and line 7241 of La Virgen in figure 4A). Moreover, we observe in onshore deposits a significant amount of normal faulting (see strikes and dips in figure 8). In offshore, the high amount of normal faulting ( NW-SE and $\sim \mathrm{NE}-\mathrm{SW})$ that affect deposits of $\mathrm{A} 1+\mathrm{A} 2$, besides the presence of strong reflectors ( $m r s$ ), allowed us to recognize and state the boundary between A1+A2 and A3. Deposits of "A1+A2" are Oligocene to Early Miocene (according to onshore data), and their progradational geometries reflect a regressive systems tract (most possibly a falling stage systems tract (FSST)).

\subsubsection{A3: onlapping deposits}

Deposits of subunit A3 are colored in light yellow. Seismic lines $\sim$ NW-SE-oriented show deposits of the subunit A3 lying above a high frequency reflector (erosional unconformity) which we considerd as a $m r s$ (see above). Lines NE-SW-oriented (lines 7241, La Vírgen, in Fig. 4A; and 7235, Mollendo, in Fig. 4B) reveal that subunit $\mathrm{A} 3$ show aggradational and even retrogradational geometries with abundant onlap terminations predominantly $\sim \mathrm{NE}$-oriented with minor channelized bodies. In this context, we consider that the onlap-dominated deposits are indicator of a relative sea- 

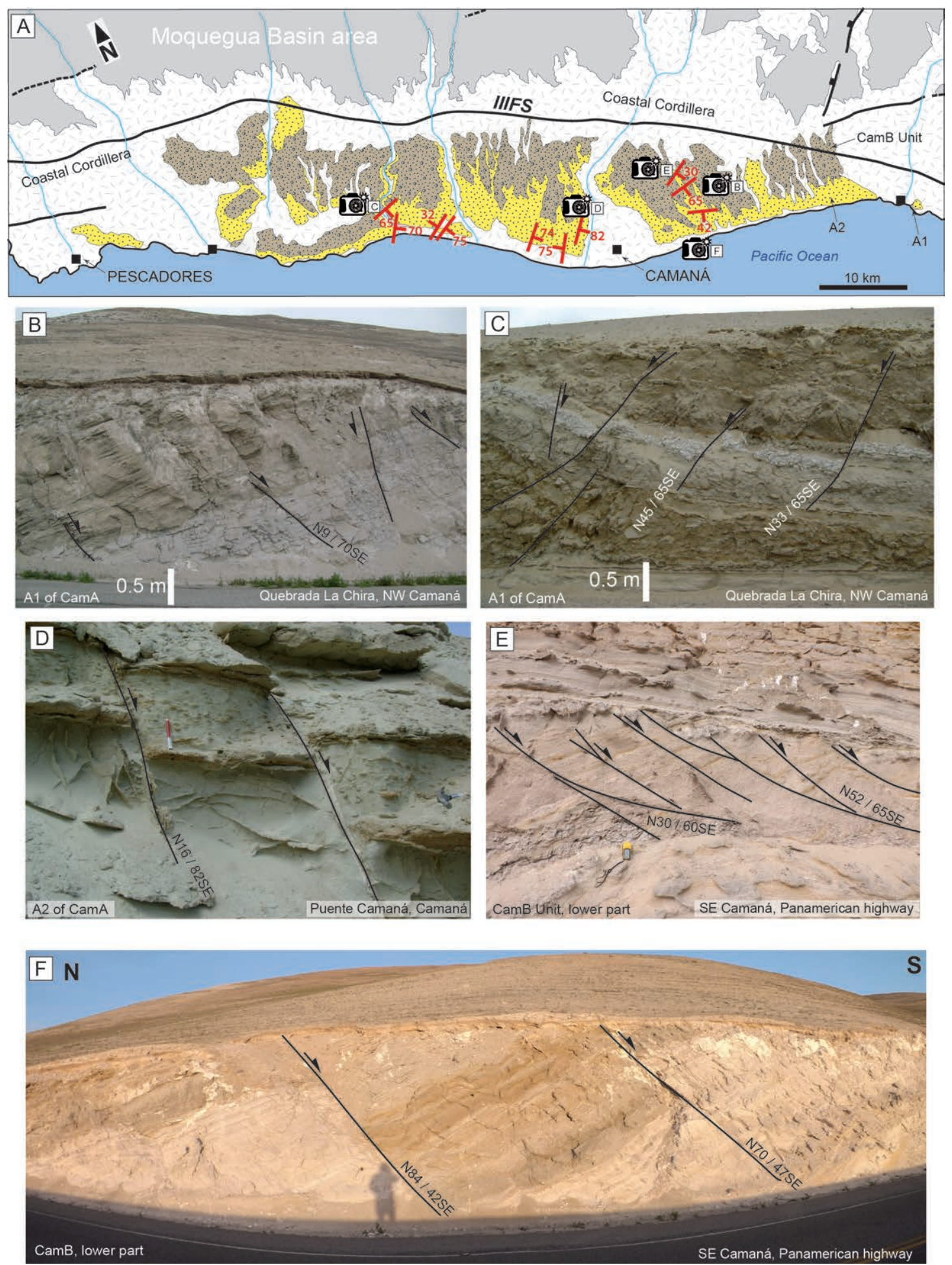

FIG. 8. Structural onshore data observed predominantly as normal faulting. A. Synthesized geological map of Camaná Formation in southwest coast of Arequipa Province; B, C and D. We observe normal faulting that affected sedimentary deposition of CamA unit, while $\mathbf{E}$ and $\mathbf{F}$ shows normal faulting that affected sedimentary deposition of CamB Unit of Camaná Formation. 
level rise that has exceeded the proportion of sediment influx onto the Camaná-Mollendo basin (transgressive systems tract). Another relevant feature to distinguish strata of A3 is the minor amount of faulting compared to the underlying " $\mathrm{A} 1+\mathrm{A} 2$ ". Despite faulting is minor, they show little synsedimentary displacements (slumps). Generally, thickness of subunit A3 is lesser than that of "A1+A2"; however, subunit A3 shows more stratigraphic thickness than "A1+A2" in the vicinity of Planchada (right part of seismic line 7090-2, Fig. 6A) and Punta de Bombón (right side of seismic line 7090-4, Fig. 5B).

Gravitational deformations such as slumps and olistostromes-type structures are common in subunit A3, as observed in line 7241 (La Vírgen, in Fig. 4A) and can be considered as mass-gravity transport deposits (MTD). In this setting, faulting is commonly attributed to gravitational factors related to an increase in the sedimentation rate capable to induce slumps, mostly if such deposits are located in a convergent area where sediment can be accreted (e.g., von Huene et al., 1996). Deposits of A3 are marked on top by a bounding surface $(\mathrm{m} f \mathrm{~s})$. This maximum flooding surface $(m f s)$ is supported by its high frequency reflectance and the progradational features of the overlying deposition (interpreted as CamB Unit) and a high-frequency reflector (e.g., line 7241, La Virgen, Fig. 4A). Deposits of A3 can be considered as potential seal rock, and they can be correlated to the strata of the Middle Miocene Pisco Formation of the Pisco Basin (see Section 8). Subunit A3 is late Early Miocene to early Middle Miocene in age, and it was deposited during a transgressive systems track (TST).

\subsubsection{CamB: progradational deposits}

According to field observations (Alván and von Eynatten, 2014), deposits of CamB unit lie above a maximum flooding surface $(\mathrm{mfs})$. Deposits of CamB Unit are represented in light green polygons in figures $3,4,5$ and 6 . These deposits change laterally (toward offshore) to deltaic deposits, showing geometries which are typical of progradational and downlapping deltas. Downlapping terminations are observed in most of CamB deposits (for instance, line 7280 of Camaná in figure 3C; line 7241 of La Virgen in figure 4A; and line 7197 of Punta de Bombón in figure 5A). Seismic lines $\sim \mathrm{NE}-\mathrm{SW}$-oriented reveal that strata of CamB are not so far affected by faulting during sedimentation; however, few graben-type fault scarps are observed in the lines, and they also can be traced along the marine floor ( $\sim 96 \mathrm{~km}$ from Pescadores to Punta de Bombón, see black continued lines in figure 7).

Deposits of CamB Unit show similar depositional geometry and probably similar nature to "A1+A2"; however, CamB deposits do not present significant synsedimentary faulting, if present, they are restricted and isolated (can be interpreted as gravitational-slides or slumps). Deposits of CamB are relatively thin in almost all seismic lines (e.g., line 7217, Punta Islay, $\sim 500 \mathrm{~m}$ thick, Fig. 4C), but in Pescadores, Camaná, and Punta de Bombón, whereas systems of $\sim$ NE-SW normal faulting are shown exceptionally concentrated (up to $\sim 2 \mathrm{~km}$ thick, see three lines in Fig. 5). In onshore, these alignments represent the large actual valleys and hold the thickest stackings of Camaná Formation, i.e., Pescadores, Camaná, Quilca, and Punta de Bombón Valleys (see below). CamB Unit is late Middle Miocene to Pliocene in age, and their sediments were deposited during a regressive systems tract.

\section{Arguments to establish stratigraphic correla- tions within deposits of the Camaná-Mollendo Basin: Correlating onshore to offshore}

We consider the latest update on the facies analysis and chrono-stratigraphy of the Cenozoic Camaná Formation by Alván and von Eynatten (2014) (Fig. 2), as well as the latest sedimentary provenance model of the Camaná Formation suggested by Alván et al. (2015), in order to characterize the deposits of Camaná Formation. The purpose is to correlate and/ or compare each deposit in onshore to its equivalent in offshore with the most consistent arguments.

According to Alván et al. (2015), the study of sedimentary provenance in Camaná Formation helped to unravel geodynamic and sedimentary processes that generated sediments, such as uplift of the basin border at Early Miocene and Late Miocene (Coastal Cordillera of southern Perú), being highly useful for hydrocarbon exploration because it is possible to predict sedimentary facies of the unseen part of the Camaná-Mollendo Basin (offshore). In this case, the best way to proceed is to define seismo-stratigraphic facies with our reinterpreted 2D-seismic data.

We use provenance arguments to correlate sediments of the basal part of the Camaná Formation termed here as subunit $\mathrm{A} 1$ with sediments of the subunit $\mathrm{MoqC} 1$ of the Moquegua Group, which is located in Internal 
Forearc. Evaluating the heavy mineral composition on sediments was widely proved as a valuable tool to correlate strata (for instance, Sheeffry Fm. in Ireland, Mange et al., 2003; Heidelberg Fm. in Central Europe, von Eynatten and Gaupp, 1999; Lower Guayabo Fm. in northern Andes, Bande et al., 2011; in Altiplano of Central Andes, Scheuber et al., 2006; and in Moquegua Group, Decou et al., 2011, 2013). For the next strata, we use predominantly depositional geometries and main erosives surfaces/sequence boundaries that are interpreted from seismic data.

\subsection{Deposits of "A1+A2"}

Based on multi-methodical analysis such as petrography of heavy minerals, geochemical analysis (LA-ICPMS), and U-Pb geochronology of zircons of reworked ash accomplished by Alván et al. (2015), it is possible to stated that sediments of CamA Unit show main sediment provenance of the rocks forming the Coastal Cordillera i.e., the San Nicolas Batholith, the Arequipa Massif, and the $\sim 24-10 \mathrm{Ma}$ Huaylillas volcanic arc (dominance of titanites and garnet). Furthermore, such authors stated that sediments of the basal part of CamA Unit (subunits $\mathrm{A} 1$ and A2) correspond in time to $\sim 30$ to $\sim 25 \mathrm{Ma}$ sediments of the hinterland Moquegua Group (MoqC Unit: Oligocene), according to the depositional ages proposed by Sempere et al. (2004) and Decou et al. (2013). Subunit MoqC1 of Moquegua Group shows dominance of piroxene, while subunit A1 shows the same minerals; however, in lower proportions. Hence, correlation between subunit A1 of Camaná Formation and subunit MoqC1 of Moquegua Group is very consistent.

Once stated the ages of subunit A1, the next step is to look for consistencies between onshore and offshore deposits in terms of depositional geometry. For instance, Alván and von Eynatten (2014) described progradational clinothems tilted toward SW observed in Camaná onshore (subunit A1), which are rather similar to deposits of "A1+A2" (highlighted in orange polygons in figures 3 and 4 ). We agree that subunits $\mathrm{A} 1$ and $\mathrm{A} 2$ were deposited during a relative sea-level fall; thus, progradational signatures are expected to represent deposits of "A1+A2" in offshore.

Onshore deposits of these subunits are eroded on top by an erosional boundary, which is indicated as a sequence boundary. If we prolongate such boundary to offshore by using ArcGIS (v.10) and graphical softwares, we observe that a high frequency reflector still represent such boundary, and marks geometrical differences between progradational "A1+A2" and the onlapping subunit A3. In this context, youngest depositional age of subunits "A1+A2" should be less than $\sim 20 \mathrm{Ma}$ and at least, more than $\sim 30 \mathrm{Ma}$ old. It is important to highlight that these deposits are more affected by normal synsedimentary faulting than the overlying subunit A3.

\subsection{Deposits of A3}

According to Alván and von Eynatten (2014), deposits of subunit A3 of Camaná Formation show onlapping geometry typical of a transgressive system tract, and lie above deposits of our grouping "A1+A2" by means of an erosive surface (maximum regressive surface, $m r s$ ). If we observe deposits above "A1+A2" (light yellow polygons in Figs. 3, 4 and 5), onlapping (and often progradational) deposits are observed. Such onlaping geometry is rather comparable to their counterpart in onshore (see Fig. 2) and it is a good argument to stablish that they are representative of subunit A3. Accordingly, depositional ages of subunit A3 should be around $20 \mathrm{Ma}$ and younger than $12 \mathrm{Ma}$.

\subsection{Deposits of CamB}

Based on sediment provenance, conglomerates and sediments of $\mathrm{CamB}$ derive predominantly from rocks of the Western Cordillera (such as Arequipa Massif, Coastal Batholith, and Tacaza Group) (Alván et al., 2015). Given the onset of intense volcanism of Lower Barroso volcanism at Late Miocene (Mamani et al., 2010) depositional ages proposed by these authors suggest that CamB Unit deposited since $\sim 12$ Ma. Rapid uplift of the Western Cordillera (basin border of Moquegua Basin) at Late Miocene is reflected in intense incision of the Colca Canyon (see Fig. 1 for location) (Schildgen et al., 2009) and also in deposition of conglomerates product of a rapid and local runoffs (CamB Unit). Accordingly, rapid deposition is consistent with rapid uplift of basin borders (Western Cordillera in the study area), which overpassed onto Camaná-Mollendo Basin. In this context, giving the similarities between progradational nature of CamB Unit in onshore and progradational geometry deposits selected in light green polygons in figures 3, 4, 5 and 6 , it is recommendable to state a correlation between these deposits (see Section 8). 


\section{The origin of depocenters in Camaná-Mollendo Basin}

Structural arrangement in forearc of southern Perú comprises components similar to wrench and graben systems (Fig. 7). This arrangement consists of (aparently) sinistral $\sim \mathrm{NW}$-SE wrench faulting that is interpreted to have facilitated uplift of the Coastal Cordillera (probably showing also sinistral behavior, i.e., IIIFS, as interpreted in Western Cordillera (Sempere and Jacay, 2006; Alván et al., 2015). A transtensive tectonic arrangement for southern Perú could be consistent with tectonic rotations as proposed Roperch et al. (2006). Schildgen et al. (2009), Decou et al. (2013), Alván et al. (2015) and Alván (2015) demonstrated that Western Cordillera in the study area experimented uplift with consequente denudation and deposition of sediments (Fig. 9). Such uplift occurred with some subsidence as offsets at the Moquegua and Camaná-Mollendo basins during deposition of CamA unit ( $\sim 30$ to $\sim 14 \mathrm{Ma})$, based on the large amount of $\sim \mathrm{NE}-\mathrm{SW}$ - and $\sim \mathrm{N}$-S-oriented synsedimentary faults that acted mostly during sedimentation of the subunits $\mathrm{A} 1$ and $\mathrm{A} 2$, and are slightly denser in the near of the submarine canyons as well as sediment accumulation (see Fig. 5).

According to Roperch et al. (2006) and Sempere and Jacay (2006), transtensional tectonics occurred as "pulses" along the forearc during Cenozoic and it was progressive, being favorable for creation of single $\sim$ NE-SW elongated depocentres (or sub-basins, e.g.,
Caravelí sub-basin, Marocco et al., 1985; Huamán, 1985) such as stackings of sedimentary rocks defined as Camaná, La Virgen, and Punta de Bombón offshore depocentres (orange circles in Fig. 7A). The statement of progressive tensional and/or transtensional phases during deposition between $\sim 30$ and $\sim 14 \mathrm{Ma}$ may explain some of the broad and thick depocentres and high concentrations of normal faults close to the submarine canyons (see seismic lines in Fig. 5) as well as several normal faults $\sim \mathrm{NE}-\mathrm{SW}$-oriented observed in onshore (Fig. 8). Simultaneously, uplift of basin borders i.e., Coastal Cordillera continued its uplift processes as well as "pulses", by means of the IIIFS (see Fig. 9 to see actual configuration).

Conversely, sediments of CamB unit are largely derived from the rocks forming the Western Cordillera and/or the Moquegua Basin, as reflected by source materials from the hinterland Arequipa Massif, Coastal Batholith, Toquepala and Tacaza Groups, and the $\sim 10-3$ Ma-old Lower Barroso volcanic products. Such sediments reflect a protracted deposition of the MoqD unit (Late Miocene to Pliocene, see light green polygons in Fig. 9) from the Moquegua Basin, and mark a drastic uplift occurred at the Western Cordillera and/or Pacific Piedmont at $\sim 12 \mathrm{Ma}$ ago (e.g., Thouret et al., 2007; Schildgen et al., 2009). Uplift of the Western Cordillera since $\sim 12$ Ma has exceeded largely the uplift of the Coastal Cordillera (Alván et al., 2015), while tectonics in offshore are probably minor than in the both Western and Coastal Cordilleras. CamB Unit consists of fluvial

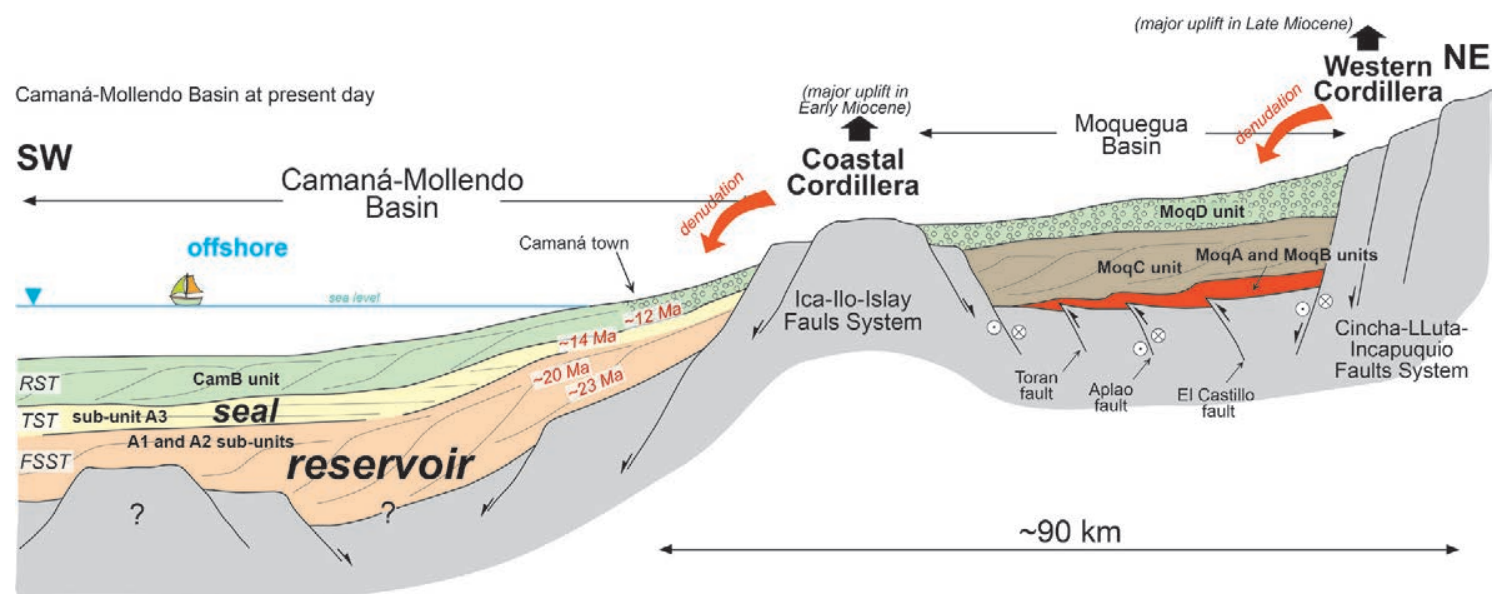

FIG. 9. Cross section of the Moquegua and Camaná Basins and the Western and Coastal Cordilleras, showing the structural and chronostratigraphic configuration at present day. Red numbers represent depositional ages according to Alván et al. (2015) and figure 2. 
facies in onshore, and very probably turns to deltaic deposits with progradational geometry in offshore. These strata show less evidences of synsedimentary faulting, as we observe in light green polygons in figures $3,4,5$ and 6 .

\section{Correlation with Pisco Basin (north) and northern Chile offshore (south)}

The Pisco Basin fill is located NW of the Camaná-Mollendo Basin (Fig. 1A), and consists of five stratigraphic units, ranging in age from Eocene to Pliocene (Macharé et al., 1986; León et al., 2008 ${ }^{3}$ ). Some lithological units are of particular interest due to their hydrocarbon reservoir potential, i.e., Caballas Formation (Early-Middle Eocene age, Macharé et al., 1986), Paracas Group (Late Eocene to Early Oligocene, Caldas, 1978; Fernández, 1993; León et al., 2008³), and Chilcatay Formation (Oligocene to Early Miocene, Dunbar et al., 1990) (Fig. 10).

Pisco Formation (Middle Miocene to Pliocene, Adams, 1906; Dávila, 1989) is considered as transgressive seal rock, blanking the entire Pisco Basin (Calderón et al., 2008; León et al., 2008³). The subunits A1 and A2 of the Camaná Formation would be chronological equivalents to the deltaic Chilcatay Formation, and the subunit A3 (here considered as potential seal rock), would be similar to the base of Pisco Formation. CamB unit can be chronologically comparable to the upper Pisco Formation of León et al. (2008) ${ }^{3}$. According to Alarcón et al. (2005), Bianchi (2005) and Calderón (2007), seismic interpretations on Cenozoic deposits of Pisco Basin fill show extensional structures that are inferred as $\sim$ NW-SE pull-apart large alignments, which are related to formation of tectonic sub-basins. Such statements support a (structurally) regional correlation between the Camaná and Pisco Basins.

On the other hand, Di Celma and Cantalamesa (2007) reported in northern Chile Miocene sediments (Caleta Herradura Formation) organized in a complex of half-graben structures deposited during a transgressive systems tract (TST), which finishes on top by a highstand systems tract (HST). As Flower and Kennet (1994), Zachos et al. (2001), and Alván and von Eynatten (2014), we agree that Middle Miocene sediments in Central Andes are mostly affected by eustassy, thus, transgressive sediments also can be correlated not only in Pisco Basin. For instance, Middle Miocene sediments of Caleta Herradura Formation in northern records consistent evidence of extreme glacio-eustatic fluctuations in sea level and suggests sea level rise at

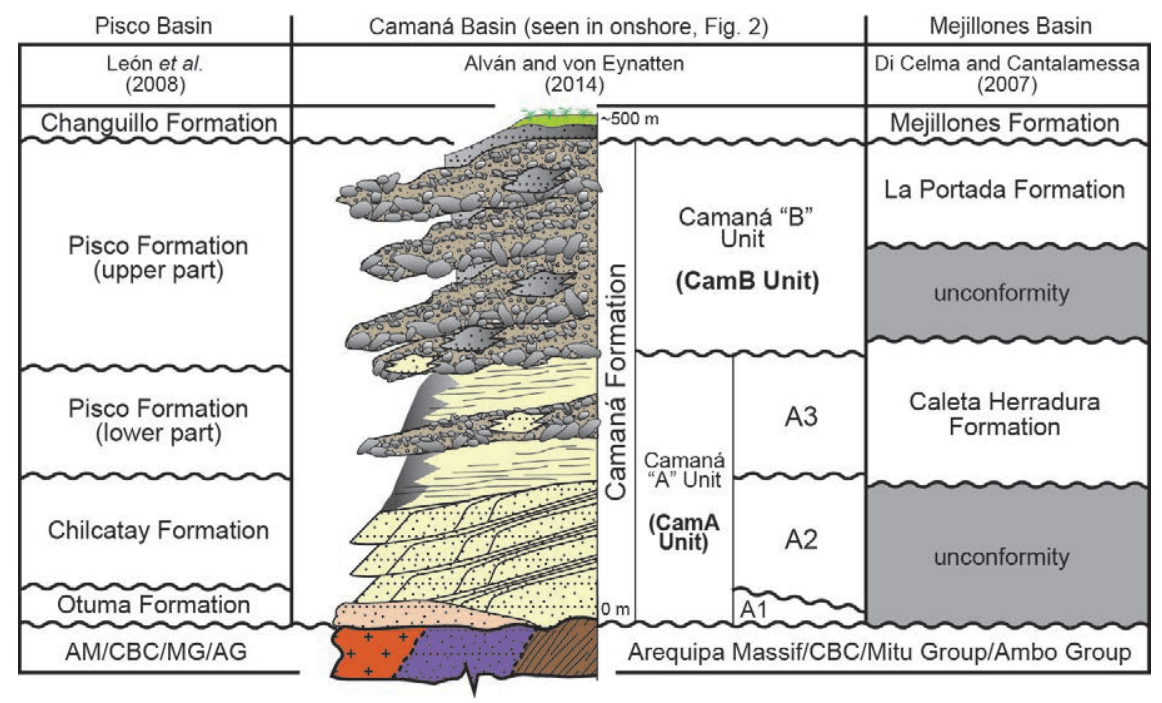

FIG. 10. Stratigraphic correlation between Camaná Formation (Camaná-Mollendo Basin), lower part of Pisco Formation and Miocene sediments of Caleta Herradura in northern Chile.

\footnotetext{
${ }^{3}$ León, W.; Aleman, A.; Rosell, W.; Torres, V.; De la Cruz, O. 2008. Estratigrafía, Sedimentología y Evolución Tectónica de la Cuenca Pisco Oriental. Dirección de Geología Regional, Instituto Geológico Minero y Metalúrgico (INGEMMET). Boletín 27, Serie D: Estudios Regionales: 161 p. Lima.
} 
around $13 \mathrm{Ma}$ (cf. Di Celma and Cantalamessa, 2007). Accordingly, we are able to trace a line of correlation for the blanking subunit A3 (Middle Miocene) among forearc basins in Central Andes (Fig. 10).

\section{Conclusions}

a. Both the Camaná Basin and the Mollendo Basin contain the Camaná Formation. The Camaná Formation in onshore presents a $\sim \mathrm{NW}$ elongated geometry, which is parallel to the trend of the major controlling faults or wrench faulting (i.e., IIIFS). Such deposits reflect the concepts of upliftrelated coarse-grained deltas, which are observed as substantial sedimentary accumulations. Camaná Formation in onshore is divided into two major depositional units, CamA and CamB. CamA is further subdivided into the subunits $\mathrm{A} 1, \mathrm{~A} 2$, and A3. Subunits A1 and A2 (grouping "A1+A2") are observed in offshore as thick deltaic progradational deposits (apparently clinothems, Oligocene to Early Miocene). Subunit A3 consists of deltaic onlapping deposits (Middle Miocene), and shows the same onlapping geometry plus minor progradational in the offshore seismic record. CamB unit consists of fluvial conglomerates in onshore (Late Miocene to Pliocene) and gets deltaic geometry and its stratigraphic thickness at offshore also increase. Erosional surfaces mark the boundaries between each depositional unit and subunit.

b. Structurally, we interpret that the Coastal Cordillera experimented uplift by means of the IIIFS during Oligocene to Early Miocene, and supported the formation of coarse-grained deltas of CamA Unit. After a minor stage of geodynamic quiescence (Middle Miocene), a later and more drastic uplift of the Western Cordillera during (Late Miocene to Pliocene) triggered deposition of fluvial conglomerates (MoqD and CamB units), being most probably progradational deltaic towards the offshore. The Camaná-Mollendo Basin consists of structural elements of a graben system with $\sim \mathrm{NW}$ SE components (Fig. 9), which are representative of an extensional tectonic regime. Such structural style is intimately related to an accretionary prism in the offshore of southern Perú, where accretionary basins affected by transtensive displacements tipically occurs (e.g., Lima sedimentary Basin, von Huene et al., 1996). This manuscript states that the origin of the depocentres is closely related to the formation of fault-related extensional movements, where grabens and half-graben structures are dominant, and allows proposing further predictions about potential reservoirs of the poorly known Camaná-Mollendo Basin fill. Simultaneously, we interpret that $\sim \mathrm{N}-\mathrm{S}$ and $\sim \mathrm{NE}-\mathrm{SW}$ alignments acted as fault-related displacements and played as well an important role in providing accommodation spaces for sedimentary depocentres in this basin. These depocentres (containing Camaná Formation) were created at least since $\sim 30 \mathrm{Ma}$ (or prior).

c. By integrating information on sediment provenance, onshore geology, and offshore seismic reinterpretation, we provide a refined stratigraphic and structural framework of the entire CamanáMollendo Basin fill and evaluate to expand the actual frontiers for hydrocarbon exploration in southern Peruvian forearc. Deltaic deposits of Camaná Formation are locally thick, and make the basin fill a potential target for hydrocarbon exploration. Similarities between the ChilcatayPisco Formations and the CamA Unit of the Camaná Formation may indicate greater untapped hydrocarbon potential. Camaná Formation is featured by its complexity in synsedimentary faulting and sand distribution, which is reflected in the generation of depocentres (Fig. 7).

\section{Acknowledgements}

The authors are grateful to Perupetro, especially to R. Bolaños (Lima) and A. Meza (Lima) for providing and processing the seismic data, to the DAAD (Deutscher Akademischer Austauschdienst), Germany, to the University of Göttingen, GZG (Department of Sedimentology and Environmental Geology), and finally to L. Lara (Santiago de Chile) and J. Becerra (Santiago de Chile) by substantial reviews. This manuscript forms part of the firsts results of the agreeement Nr. 216-2015 (FONDECYT-INGEMMET) of Perú, project "GeoSed Perú".

\section{References}

Acosta, H.; Rodríguez, J.; Ccallo, W.; Cutipa, M. 2012. Actividad Tectónica del Sistema de Fallas CinchaLluta-Incapuquio durante el Cretácico y Palógeno en el Sur del Perú. In Congreso Peruano de Geología, No. 16, Sociedad Geológica del Perú, Resúmenes Extendidos: 5 p. Lima.

Adams, J.L. 1906. Caudal, procedencia y distribución de aguas de los departamentos de Arequipa, Moquegua 
y Tacna. Boletín del Cuerpo de Ingeniero de Minas del Perú 45: 56-63.

Alarcón, P.; Anzoleaga, R.; Gonzales, E.; Bianchi, C.; Fuentes, J. 2005. Estilos estructurales y evolución de las cuencas Costafuera del Perú y su potencial Hidrocarburifero. In Congreso Internacional de Exploración, Explotación, Procesamiento y Transporte de Hidrocarburos (INGEPET), No. 5, EXPR-3-CB-33: 11 p. Lima.

Alván, A. 2015. Geodynamic significance of the Cenozoic deposits in the southern Peruvian forearc $\left(16^{\circ} 25^{\prime} \mathrm{S}\right.$ to $\left.17^{\circ} 15^{\prime} \mathrm{S}\right)$ : constraints by facies analysis and sediment provenance. Ph.D. Thesis (Unpublished), University of Gottingen, Germany: 145 p.

Alván, A.; von Eynatten, H. 2014. Sedimentary facies and stratigraphic architecture in coarse-grained deltas: Anatomy of the Cenozoic Camaná Formation, Southern Perú (16 $25^{\prime}$ S to $17^{\circ} 15^{\prime}$ S). Journal of South American Earth Sciences 54: 82-108.

Alván, A.; von Eynatten, H.; Dunkl, I.; Gerdes, A. 2015. Zircon $\mathrm{U}-\mathrm{Pb}$ geochronology and heavy mineral analysis of the Camaná Formation, southern Perú (16 $25^{\circ} \mathrm{S}$ to $\left.17^{\circ} 15^{\prime} \mathrm{S}\right)$ : constraints to sediment provenance and exhumation of the Coastal and Western cordilleras. Journal of South American Earth Sciences 61: 14-32.

Apolín, J. 2001. Isurus oxyrinchus Rafinesque, 1810 "mako de aletas cortas" como posible ancestro de Carcharodon carcharias (Linnaeus, 1758) "tiburón blanco" (Chondrichtyes: Lamnidae). Universidad Nacional Mayor de San Marcos: 133 p. Perú.

Bande, A.; Horton, B.; Ramírez, J.; Mora, A.; Parra, M.; Stockli, D. 2011. Clastic deposition, provenance and sequence of Andean thrusting in the frontal Eastern Cordillera and Llanos foreland basin of Colombia. Geological Society of America Bulletin 124: 59-76.

Bianchi, C. 2005. Estilos Estructurales y Evolución de las Cuencas Costafuera del Perú y su potencial Hidrocarburifero. In Congreso Internacional de Exploración, Explotación, Procesamiento y Transporte de Hidrocarburos (INGEPET), No. 5, Technical Abstracts EXPR-3-CB-33: 41 p. Lima.

Bowring, S.A.; Schmitz, M.D. 2003. High-Precision $\mathrm{U}-\mathrm{Pb}$ Zircon Geochronology and the Stratigraphic Record. Reviews in Mineralogy and Geochemistry 53 (1): 305-326.

Caldas, J. 1978. Geología de los cuadrángulos de San Juan, Acarí y Yauca. Instituto de Geología y Minería, Boletín 30: 78 p. Lima.

Calderón, Y. 2007. Arquitectura estructural y estratigráfica de la Cuenca de ante-arco Neógena de Pisco (Perú) sobre la subducción de la Dorsal de Nazca. Master Thesis (Unpublished), Sciences de la Terre et de 1'Université Toulouse III Paul Sabatier: 34 p. France.

Calderón, Y.; Baby, P.; Brusset, S.; Bolaños, R. 2008. Neogene Tectono-Sedimentary record of the Nazca Ridge subduction in the Pisco basin, and consequences on the Petroleum System. In Congreso Internacional de Exploración, Explotación, Procesamiento y Transporte de Hidrocarburos (INGEPET), No. 6, EXPR-3-YC-22: 13 p. Lima.

Catuneanu, O. 2002. Sequence stratigraphy of clastic systems: concepts, merits, and pitfalls. Journal of African Earth Sciences 35: 1-43.

Catuneanu, O.; Abreu, V.; Bhattacharya, J.; Blum, M.; Dalrymple, R.; Eriksson, P.; Fielding, C.; Fisher, W.; Galloway, W.; Gibling, M.; Giles, K.; Holbrook, J.; Jordan, R.; Kendall, C.; Macurda, B.; Martinsen, O.; Miall, A.; Neal, J.; Nummedal, D.; Pomar, L.; Posamentier, H.; Pratt, B.; Sarg, J.; Shanley, K.; Steel, R.; Strasser, A.; Tucker, M.; Winkler, C. 2009. Towards the standarization of sequence stratigraphy. Earth-Science Reviews 92: 1-33.

Colella, A. 1988. Fault-controlled marine Gilbert-type fan deltas. Geology 16: 1031-1034.

Dávila, D. 1989. Estratigrafía cenozoica del Valle del Río Grande, Cuenca de Pisco, Perú. Sociedad Geológica del Perú, Boletín 80: 65-76.

Decou, A.; von Eynatten, H.; Mamani, M.; Sempere, T.; Wörner, G. 2011. Cenozoic forearc basin sediments in Southern Perú $\left(15-18^{\circ} \mathrm{S}\right)$ : stratigraphic and heavy mineral constraints for Eocene to Miocene evolution of the Central Andes. Sedimentary Geology 237: 55-72.

Decou, A.; Von Eynatten, H.; Dunk1, I.; Wörner, G. 2013. Late Eocene to Early Miocene Andean uplift inferred from detrital zircon fission track and $\mathrm{U}-\mathrm{Pb}$ dating of Cenozoic forearc sediments $\left(15-18^{\circ} \mathrm{S}\right)$. Journal of South American Earth Sciences 45: 6-23.

DeVries, T.J. 1998. Oligocene deposition and Cenozoic sequence boundaries in the Pisco Basin (Perú). Journal of South American Earth Sciences 11 (3): 217-231.

Di Celma, C.; Cantalamessa, G. 2007. Sedimentology and high-frequency sequence stratigraphy of a forearc extensional basin: The Miocene Caleta Herradura Formation, Mejillones Peninsula, northern Chile. Sedimentary Geology 198: 29-52.

Dunbar, R.; Marty, R.; Baker, P. 1990. Cenozoic marine sedimentation in the Sechura and Pisco basins, Perú. Palaeogeography, Palaeoclimatology, Palaeoecology 77: 235-261. 
Ellison, R.A.; Klinck, B.A.; Hawkins, M.P. 1989. Deformation events in the Andean orogenic cycle in the Altiplano and Western Cordillera, southern Perú. Journal of South American Earth Sciences 2 (3): 263-276.

Fernández, M. 1993. Geología de los cuadrángulos de Pisco, Guadalupe, Punta Grande, Ica y Córdova. Carta Geológica Nacional del Perú. Instituto Geológico Minero y Metalúrgico (INGEMMET). Boletín 47 (A): 62 p. Lima.

Flower, B.; Kennett, J. 1994. The middle Miocene climatic transition: East Antarctic ice sheet development, deep ocean circulation and global carbon cycling. Palaeogeography, Palaeoclimatology, Palaeoecology 108: 537-555.

Hagen, R.A. 1993. Fault patterns on the outer wall of the Perú-Chile trench. Geo-Marine Letters 13: 139-144.

Haq, B.; Hardenbol, J.; Vail, P. 1987. Chronology of Fluctuating Sea Levels Since the Triassic (250 Myr ago to present). Science 235: 1156-1167.

Hardenbol, J.; Thierry, J.; Farley, M.; Jacquin, T.; De Graciansky, P.C.; Vail, P. 1998. Mesozoic and Cenozoic sequence chronostratigraphic framework of Europeans basins. In Mesozoic and Cenozoic Sequence Stratigraphy of Europeans Basins (Graciansky, P.C.; Hardenbol, J.; Jacquin, T.; Vail, P.; editors). Society for Sedimentary Geology, Special Publication 60 (1-8): 3-13.

Huamán, R. 1985. Evolution tectonique cenozoique et neotectonique du Piemont Pacifique dans la región d'Arequipa (Andes du Sud Perou). Tesis de Doctorado (Unpublished), Universidad de París: 220 p. París.

Ibaraki, M. 1992. Neogene planktonic Foraminifera of the Camana Formation, Perú: Their geologic age and implications. Reports of Andean Studies, Shizuoka University, Special Volume 4, Reports of Andean Studies: 9-19.

Isacks, B.L. 1988. Uplift of the Central Andean plateau and bending of the Bolivian orocline. Journal of Geophysical Research 93: 3211-3231.

Jacay, J.; Sempere, T.; Husson, L.; Pino, A. 2002. Structural Characteristics of the Incapuquio Fault System, Southern Perú. In International Symposium on Andean Geodynamics, No. 5, Extended Abstracts: 319-321. Toulouse.

Jordan, T.E.; Isacks, B.L.; Allmendinger, R.W.; Brewer, J.A.; Ramos, V.A.; Ando, C.J. 1983. Andean tectonics related to geometry of subducted Nazca Plate. Geological Society of America Bulletin 94 (3): 341-361.

Macharé, J.; Sébrier, M.; Huaman, D.; Mercier, J.L. 1986. Tectónica Cenozoica de la Margen Continental Peruana. Boletín de la Sociedad Geológica del Perú 76: 45-77.
Mahlburg-Kay, S. 2005. Tertiary to Recent evolution of Andean arc and backarc magmas between $36^{\circ} \mathrm{S}$ and $38^{\circ} \mathrm{S}$ and evidence for Miocene shallowing of the Nazca plate under the Neuquen basin. In International Symposium on Andean Geodynamics, No. 6, Extended Abstracts: 420-423. Barcelona.

Mahlburg-Kay, S.; Godoy, E.; Kurtz, A. 2005. Episodic arc migration, crustal thickening, subduction erosion, and magmatism in the south-central Andes. Geological Society of America Bulletin 117 (1-2): 67-88.

Mamani, M.; Wörner, G.; Sempere, T. 2010. Geochemical variations in igneous rocks of the Central Andean orocline $\left(13^{\circ} \mathrm{S}\right.$ to $\left.18^{\circ} \mathrm{S}\right)$ : Tracing crustal thickening and magma generation through time and space. Geological Society of America 122: 162-182.

Mange, M.A.; Dewey, J.F.; Wright, D.T. 2003. Heavy minerals solve structural and stratigraphic problems in Ordovician strata of the western Irish Caledonides. Geological Magazine 140 (1): 25-30.

Marocco, R.; Noblet, C. 1990. Sedimentation, tectonism and volcanism relationships in two Andean basins of southern Perú. Geologische Rundschau 79 (1): 111-120.

Marocco, R.; Delfaud, J.; Lavenu, A. 1985. Ambiente deposicional de una cuenca continental intramontañosa andina: el Grupo Moquegua (sur de Perú) primeros resultados. Sociedad Geológica del Perú, Boletín 75: 73-90.

Oncken, O.; Hindle, D.; Kley, J.; Elger, K.; Victor, P.; Schemmann, K. 2006. Chapter 1: Deformation of the Central Andean Upper Plate System-Facts, Fiction, and constrains for the Plateau Models. In The Andes, Active Subduction Orogeny (Oncken, O.; Chong, G.; Franz, G.; Giese, P.; Götze, H.J.; Ramos, V.A.; Strecker, M.R.; Wigger, P.; editors). Springer-Verlag Berlin Heidelberg: 1-27. Berlín.

Palacios, O. 1995. Geología del Perú. Dirección de Geología Regional, Instituto Geológico Minero y Metalúrgico (INGEMMET), Carta Geológica Nacional, Boletín 55 (A): 156 p. Perú.

Palacios, O.; Chacón, N. 1989. Evolución geomofológica del territorio Peruano. Sociedad Geográfica de Lima: 12 p.

Pecho, V.; Morales, G. 1969. Geología de los Cuadrángulos de Camaná y La Yesera. Dirección de Geología Regional, Instituto Geológico Minero y Metalúrgico (INGEMMET), Carta Geológica Nacional, Boletín 21 (A): 72 p.

Rivera, R. 1950. Geología del Valle de Camaná y Majes. Tesis de Grado (Unpublished), Universidad Nacional San Agustín: 100 p. Arequipa. 
Roperch, P.; Sempere, T.; Macedo, O.; Arriagada, C.; Fornari, M.; Tapia, C.; García, M.; Laj, C. 2006. Counterclockwise rotation of late Eocene-Oligocene fore-arc deposits in southern Perú and its significance for oroclinal bending in the central Andes. Tectonics 25 (3): 29 p.

Scheuber, E.; Mertmann, D.; Ege, H.; Silva-González, P.; Heubeck, C.; Reutter, K.J.; Jacobshagen, V. 2006. Chapter 13: Exhumation and basin development related to formation of the Central Andean Plateau, $21^{\circ} \mathrm{S}$. In The Andes, Active Subduction Orogeny (Oncken, O.; Chong, G.; Franz, G.; Giese, P.; Götze, H.-J.; Ramos, V.; Strecker, M.; Wigger, P.; editors), Springer: 285-301.

Schildgen, T.; Hodges, K.; Whipple, K.; Pringle, M.; van Soest, M.; Cornell, K. 2009. Late Cenozoic structural and tectonic development of the western margin of the central Andean Plateau in southwest Perú. Tectonics 28: $21 \mathrm{p}$.

Sébrier, M.; Macharé, J.; Marocco, R. 1984. Evolution cenozoique du piémont pacifique et sa relation avec la Cordillere des Andes du Pérou central et méridional. Revue des Géographes des Pyrénées et du Sud-Ouest: 49-69. Tolouse.

Sempere, T.; Jacay, J. 2006. Estructura tectónica del sur del Perú (Antearco, arco, y altiplano suroccidental). In Congreso Peruano de Geología, No. 13, Resúmenes Extendidos: 324-327. Lima.

Sempere, T.; Fornari, M.; Acosta, J.; Flores, A.; Jacay, J.; Peña, D.; Roperch, P.; Taipe, E. 2004. Estratigrafía, geocronología y paleotectónica de los depósitos de antearco del sur del Perú. In Congreso Peruano de Geología, No. 12, Resúmenes Extendidos: 533-536. Lima.

Steinmann, G. 1930. Geologie von Perú. Winter, Heidelberg: $448 \mathrm{p}$.

Thouret, J.C.; Wörner, G.; Gunnell, Y.; Singer, B.; Zhang, X.; Souriot, T. 2007. Geochronologic and stratigraphic constrains on canyon incision and Miocene uplift of the Central Andes in Perú. Earth and Planetary Science Letters 263: 151-166.

Tsuchi, R.; Shuto, T.; Takayama, T.; Koizumi, I.; Fujiyoshi, A.; Ibaraki, M.; Aldana, M.; Villavicencio, E. 1990. Fundamental data on Cenozoic biostratigraphy of the Pacific Coast of Perú-Suplement. Reports of Andean Studies, Shizuoka University, Special Volume 3: 47-57.

Vail, P.; Todd, R.G.; Sangree, J.B. 1977. Seismic Stratigraphy and Global Changes of Sea Level: Part 5. Chronostratigrahic Significance of Seismic Reflections. Section 2. Application of Seismic Reflection Configuration to Stratigraphic Interpretation. American Association of Petroleum Geologists (AAPG) Bulletin, Memoir 26: 99-116.

Vega, M. 2002. La cuenca de Antearco del sur del Perú: dinámica de la sedimentación y contexto geodinámico de la Formación Camaná y sus equivalentes Off-shore. Tesis de Grado (Unpublished), Universidad San Antonio de Abad del Cusco: 182 p. Perú.

Von Eynatten, H.; Gaupp, R. 1999. Provenance of Cretaceous synorogenic sandstones in the Eastern Alps: constraints from framework petrography, heavy mineral analysis and mineral chemistry. Sedimentary Geology 124 (1-4): 81-111.

Von Eynatten, H.; Dunkl, I. 2012. Assessing the Sediment Factory: The Role of Single Grain Analysis. EarthScience Reviews 115: 97-120.

Von Huene, R.; Lallemand, S. 1990. Tectonic erosion along the Japan and Perú convergent margins. Geological Society of America Bulletin 102 (6): 704-720.

Von Huene, R.; Pecher, I.A.; Gutscher, M.A. 1996. Development $f$ the accretionary prism along Perú and material flux after subduction of Nazca Ridge. Tectonics 15 (1): 19-33.

Williams, G.D. 1993. Tectonics and seismic sequence stratigraphy: an introduction. Geological Society, Special Publication 71: 1-13.

Wörner, G.; Hammerschmidt, K.; Henjes-Kunst, F.; Lezaun, J.; Wilke, H. 2000. Geochronology $\left({ }^{40} \mathrm{Ar} /{ }^{39} \mathrm{Ar}\right.$, $\mathrm{K}-\mathrm{Ar}$ and $\mathrm{He}$-exposure ages) of Cenozoic magmatic rocks from northern Chile $\left(18-22^{\circ} \mathrm{S}\right)$ : implications for magmatism and tectonic evolution of the central Andes. Revista Geológica de Chile 27 (2): 206-239. doi: 10.5027/andgeoV27n2-a04.

Zachos, J.; Pagani, M.; Sloan, L.; Thomas, E.; Billups, K. 2001. Trends, rhythms, and aberrations in global climate 65 Ma to present. Science 292: 686-693.

Manuscript received: February 15, 2016; revised/accepted: October 24, 2016; available online: October 27, 2016. 